\title{
La rappresentazione dello spazio nei videogiochi
}

\author{
Greta Attademo
}

Abstract

La ricerca indaga il linguaggio visivo nel videogioco, inteso come forma comunicativa emblematica dell'età contemporanea. In particolare, si analizza la rappresentazione dello spazio, in quanto elemento comune e centrale in tutte le narrazioni visuali prodotte dall'uomo, siano esse immagini statiche oppure dinamiche. II tema proposto, seppur in parte affrontato nel campo dei game studies, non ha ancora trovato pieno riscontro negli studi dell'ambito disciplinare del disegno, probabilmente data l'origine recente del mezzo videoludico. Poiché ogni forma di narrazione visiva riprende e rielabora codici e linguaggi dai mezzi che l'hanno preceduta, dotandoli di nuovo significato, il metodo di analisi scelto prevede una comparazione tra spazi pittorici e videoludici. Le teorie relative alla costruzione della rappresentazione spaziale in un'arte tradizionale, distante per origine temporale, tipologia di immagini e finalità narrative, permettono, infatti, di mostrare più chiaramente riproposizioni e peculiarità del nuovo medium. I risultati ottenuti consentono di definire le relazioni possibili tra disegno, narrazione e gameplay, costituendo, inoltre, una base per la catalogazione degli spazi rappresentati nei videogiochi da parte dell'area scientifica del disegno.

Parole chiave

videogiochi, gamespace, spazio narrativo, cultura visiva, storytelling.

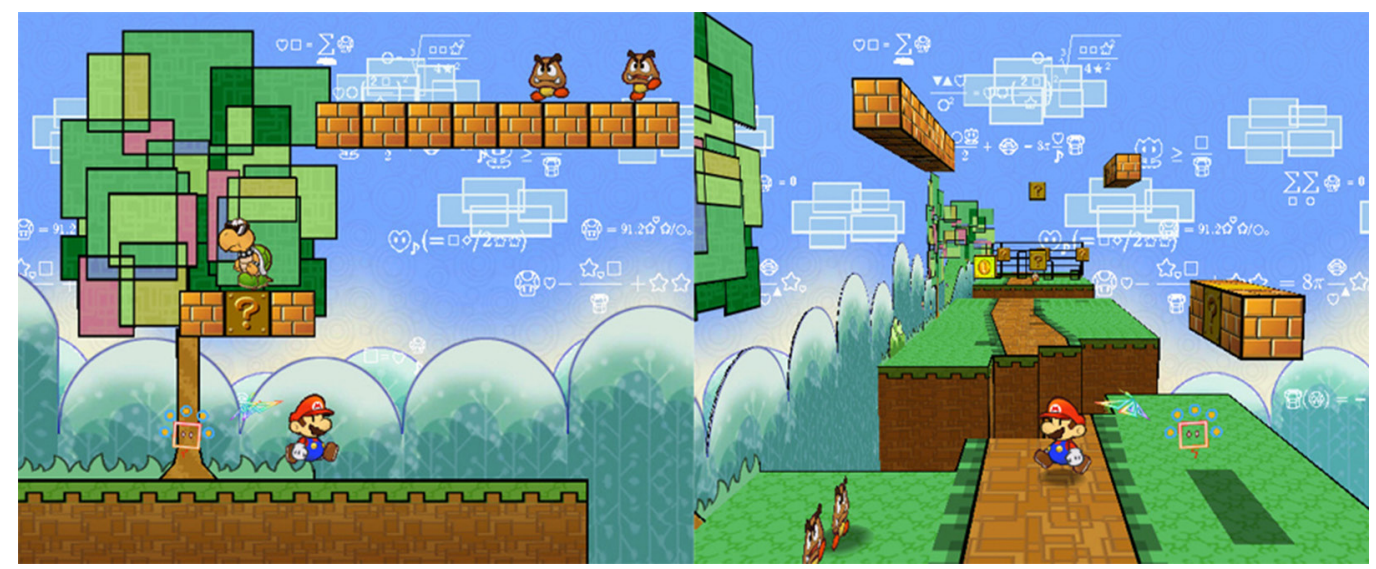




\section{Introduzione}

La rappresentazione visiva accompagna la storia dell'uomo fin dalla sua nascita, rispondendo alla sua esigenza di narrare la propria percezione del mondo attraverso un codice sintetico e universale [McCloud 1994]. Nel corso dei secoli, essa è stata efficace quando interpretativa del rapporto tra uomo e mondo, rivelando la percezione della realtà in cui si andava affermando [Maldonado 20 I5]. II videogioco, la cui natura intrinseca vede convergere linguaggio visivo, tecnologia ed esperienza ludica è l'emblema dell'epoca contemporanea, dominata da una fusione intercategoriale [Simondon 20 I4] tra essere umano, artefatti digitali e mondo esterno. Come osserva Gianfranco Pecchinenda, "l'uomo contemporaneo ha un'immagine di sé che può essere metaforicamente rappresentata da un videogame, nel senso che egli ritiene sé stesso un'entità materiale predisposta a ricevere, elaborare e comunicare informazioni con una realtà esterna composta 'indifferentemente' da entità simili a sé, oppure da entità puramente immateriali"' [Pecchinenda 20I0, p. I28]. Considerando che l'immagine è percepita prima del gioco [Gunzel 2008] e che "la componente visuale non è la dimensione esclusiva dell'esperienza ludica ed estetica, ma indubbiamente la più pervasiva" [De Leo 2007, p. 28 I], l'analisi del videogioco può ridefinire la nostra relazione con le narrazioni per immagini [Wolf, Perron, 2003]. Sebbene "non sono pochi coloro che pensano che il nostro specifico non sia la sola architettura, bensi l'elaborazione di immagini visive" [Cardone 20 I9, p. 19], nella nostra disciplina non sembra ancora essersi radicata la necessità di affrontare tale tematica che, di contro, vede una partecipazione sempre più intensa di disegnatori e architetti nella realizzazione dei prodotti videoludici. Così come nelle altre narrazioni visive, infatti, anche nei videogiochi è affidato un ruolo centrale alla rappresentazione spaziale, non solo figurazione dei luoghi deputati all'azione, ma anche categoria entro cui s'inseriscono tutti gli elementi funzionali al racconto [Zoran 1984]. II videogioco, però, è l'unico mezzo che assomma dinamismo visivo e ruolo partecipativo attivo [Greenfield 1984]. Se negli altri media la narrazione è di tipo 'causa-effetto', e il ruolo dello spettatore è osservare dall'esterno le dinamiche del racconto, nel videogioco l'interazione rompe questo meccanismo. II giocatore è al centro della storia, è lui a costruirla attraverso le sue azioni [Adams 2002]. La capacità "di manipolare le immagini riprodotte a schermo" [Alinovi 2002, p. 17], comporta una nuova relazione anche con lo spazio. Risulta interessante, dunque, indagare i linguaggi visivi del videogame mantenendo la spazialità come fulcro della ricerca. Poiché il videogioco ricicla e reinventa i codici dei media tradizionali [Fraschini 2002], si decide di confrontarne le rappresentazioni con quelle provenienti dall'arte pittorica. Quest'ultima, che appare come il mezzo narrativo più distante dai videogiochi, per origine temporale, staticità delle immagini e componente 'analogica', permette di mostrare più chiaramente riproposizioni e peculiarità del nuovo medium.

\section{La rappresentazione dello spazio in relazione al reale}

Gli studi sull'arte visuale hanno mostrato come, all'interno di ogni contesto socioculturale, sia individuabile un sistema di immagini attraverso le quali ci si impadronisce della realtà, individuando modalità di rappresentazione differenti che rivelano "il modo particolare con cui l'uomo vi abita lo spazio e i rapporti mentali che intrattiene con esso" [Zumthor 1995, p. 337]. Peter Zumthor distingue le immagini 'concettuali' da quelle 'figurative', a seconda che operino "per mezzo del linguaggio o delle arti mimetiche" [Zumthor, 1995, p. 15]. Anche Agostino De Rosa ritiene che l'approccio alla rappresentazione spaziale possa essere definito 'concettuale' in quelle immagini "che pur caratterizzando antiche e raffinate civiltà artistiche $[\ldots]$ non ritennero utile fondare le proprie convenzioni rappresentative sulla verosimiglianza, pur nella consapevolezza del fenomeno oggettivo della prospettiva naturale" [De Rosa et al. 2000, p. I5]. Per la categoria opposta, invece, parla di immagini 'visive', in quanto "il realismo, infatti, non è solo di tipo visivo, non si caratterizza cioè soltanto nell'imitare di un oggetto il modo in cui appare all'osservatore, ma si potrebbe alternativamente parlare di realismo metrico, cioè della restituzione grafica di alcuni valori dimensionali che si ritengono 
oggettivamente caratterizzanti una data forma" [De Rosa et al. 2000, p. I5]. Si distinguono, pertanto, due tipologie di rappresentazione:

- spazio concettuale. Non tenta di realizzare alcun tipo di realismo visivo, inteso come rappresentazione verosimigliante per l'occhio umano, ma riproduce le qualità distintive dell'aspetto reale dello spazio;

- spazio visivo. Rappresenta lo spazio per come appare agli occhi dell'osservatore, riproponendone la visione fisiologica.

Tali categorie rispondono agli antipodi spaziali descritti da Rudolf Arnheim per le composizioni pittoriche; non tutte le rappresentazioni sono confinate in queste estremità ma, di fatto, protendono sempre verso una delle due. La prima, "a costanza allo 0\%", in cui il disegno dello spazio si riduce alla bidimensionalità di un solo piano frontale; la seconda, "a costanza al 100\%", in cui lo spazio è mostrato in una scena pienamente tridimensionale [Arnheim 2008, p. I I 5]. L'analisi di alcuni esempi pittorici, dichiaratamente concettuali o visivi, diventa una linea guida per lo studio degli spazi videoludici.

\section{Spazi concettuali. Dalla pittura egizia a Pacman}

La pittura egizia è uno degli esempi più chiari della rappresentazione dello spazio concettuale (fig. I). Gli egizi utilizzavano le proiezioni ortogonali non perché non fossero a conoscenza della percezione fisiologica dell'occhio, né tantomeno perché non esistesse un procedimento scientifico adoperabile (la pittura romana, ad esempio, simulava la tridimensionalità dello spazio pur non essendo stato ancora codificato il metodo prospettico), ma perché lo preferivano. Questo metodo, infatti, permette di conservare i caratteri maggiormente riconoscibili dello spazio [Arnheim 2008], comunicando differenti e complesse sequenze narrative
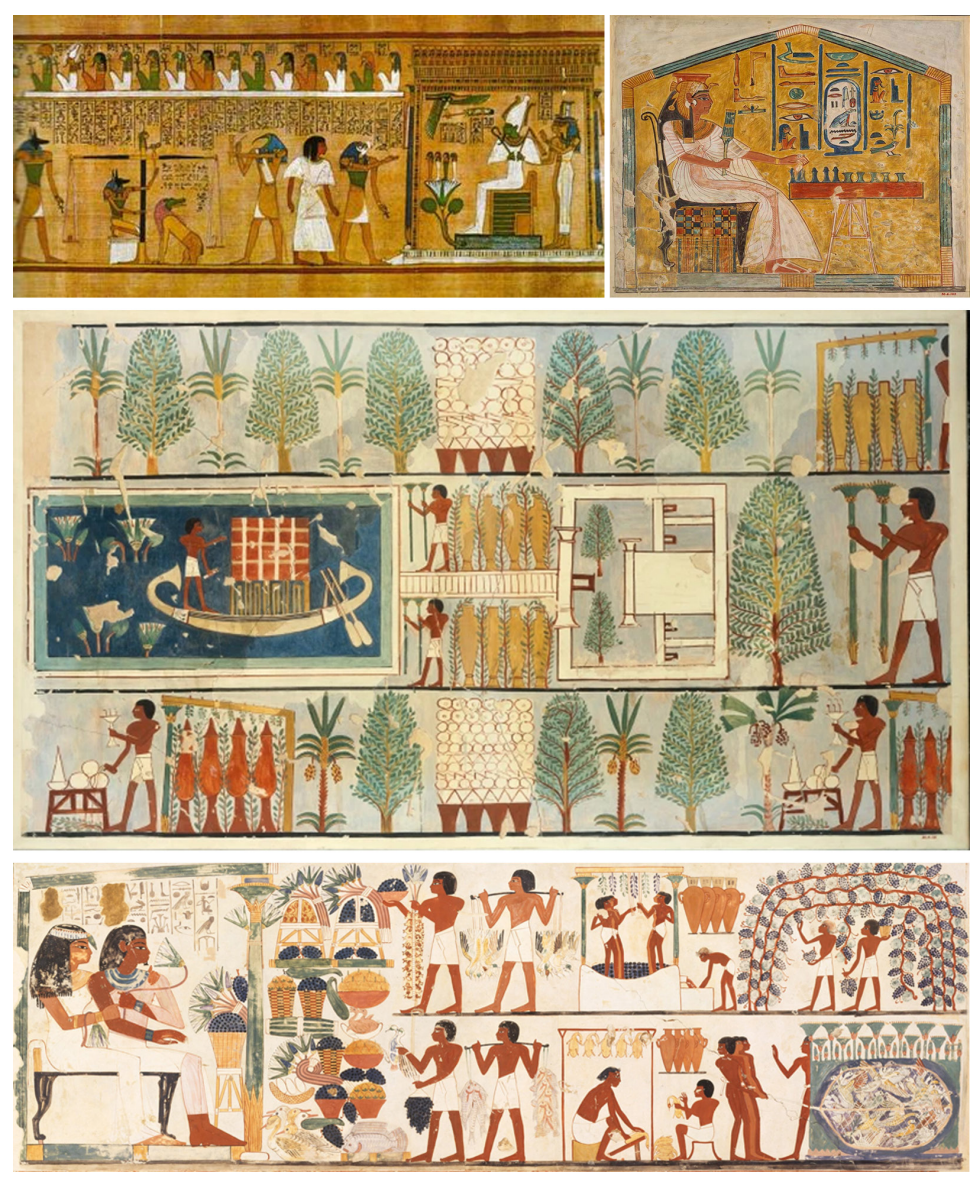
attraverso pochi e intuitivi segni. Le figure bidimensionali, stagliandosi su fondi neutri, sono rappresentate nel loro profilo più riconoscibile, spesso scomponendone e ricomponendone le parti per metterne in evidenza le qualità più significative. II Giardino di Nebamun (fig. 2), un frammento di pittura murale risalente al I 400 a.C. circa, mostra una visione globale dello spazio. La piscina è in pianta, poiché tale proiezione permette di conservare i parametri di lunghezza e larghezza, altrimenti non osservabili con altri metodi di rappresentazione. La fauna, costituita da pesci e anatre, è in prospetto laterale, così da mostrare piume e pinne che, seppur schematiche, sono indispensabili al riconoscimento delle specie animali. La flora, in prospetto frontale, rende visibile non solo la chioma delle piante, ma anche fusti, rami e frutta, identificando così le varie tipologie arboree, come la palma e il sicomoro. Gli alberi, inoltre, ribaltati lungo i lati, indicano la loro posizione rispetto la piscina. Lo spazio concettuale risponde alla volontà di narrare il giardino come icona della rigogliosità e della

Fig. 2. II giardino ideale, frammento dalla tomba di Nebamon (TTI46), Tebe, XVIII dinastia, Londra, British Museum. Schema della rappresentazione concettuale dello spazio.
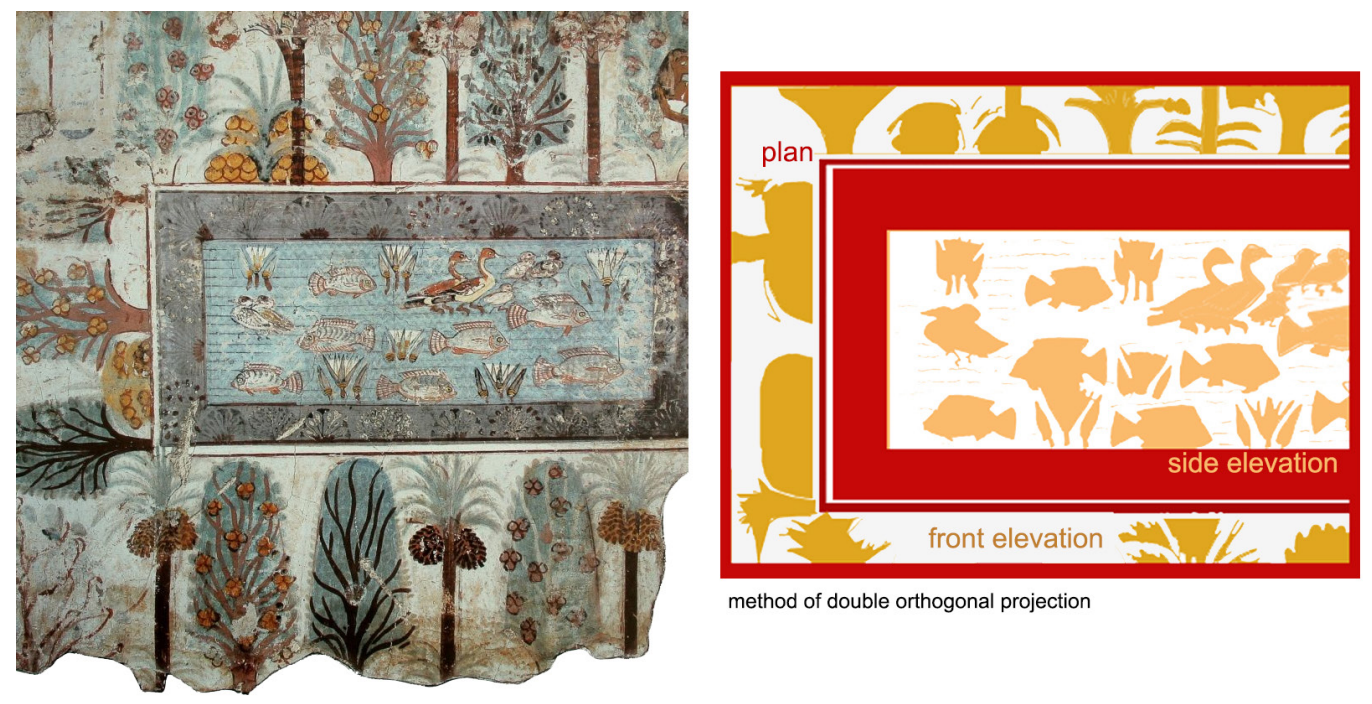

method of double orthogonal projection

Conceptual Space in painting

variegata ricchezza della civiltà egizia, resa possibile dalle condizioni climatiche e dalla fertilità del terreno. Anche nel videogame Pacman (figg. 3,4 ) un'inquadratura fissa mostra l'intero gamespace. Il labirinto è in prima proiezione ortogonale, dando così una visione simultanea di tutti i percorsi. II profilo laterale dell'avatar Pacman ne inquadra l'apertura della bocca, in una vista dall'alto altrimenti non visibile, connettendola alla finalità del gioco di mangiare gli elementi puntuali posti lungo i percorsi. I fantasmi, invece, sono in prospetto frontale che, mostrandone entrambi gli occhi, ne comunica l'abilità di seguire tutti i movimenti di Pacman, così da raggiungerlo e bloccarlo. La superficie distesa e piatta del labirinto, rimarcata dallo sfondo nero, consente di navigare lo spazio solo attraverso scorrimenti laterali. La sovrapposizione di piani spaziali in una condivisa superficie bidimensionale restituisce una costruzione artefatta, dominata dalla compresenza di tutti gli elementi interni al labirinto. II giocatore, dunque, riceve tutte le informazioni spaziali attraverso un unico atto percettivo. II suo punto di vista, posto all'infinito, non coincide con quello dell'avatar, e ciò permette di scorgere oltre i muri, visualizzare la posizione dei nemici e controllare lo spazio visibile. L'astrazione degli elementi (colori puri, forme stilizzate, luci endogene, assenza di ombreggiature/riflessi) rimarca la chiarezza con cui lo spazio si mostra alla visione istantanea del giocatore. II fuoricampo, quindi, non contiene elementi narrativi da svelare tramite un'esplorazione, ossia reimpostando i confini dell'inquadratura. Sebbene esistano spazi concettuali che hanno 
Fig. 3. La rappresentazione dello spazio concettuale. Confronto tra il

videogioco Pacman e il dipinto murale Giardino di Rekhmire, tomba di Rekhmire, Sheikh Abd el-Qurna, I 400 a.C.ca.
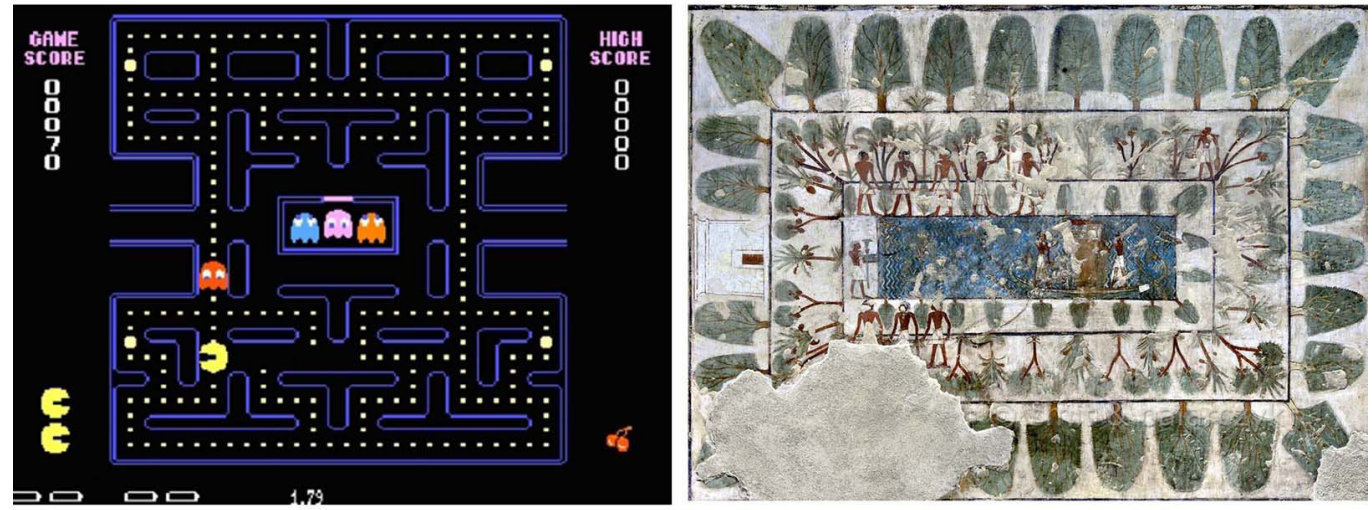

relazioni con il fuori schermo, al giocatore non ne è mai consentito il controllo del campo visivo. In Asteroids (fig. 5), ad esempio, alcuni oggetti attraversano i confini della superficie bidimensionale, ricomparendo nel lato speculare a quello della loro fuoriuscita. L'azione della navicella-avatar, invece, si consuma entro i confini dell'inquadratura, che non può essere modificata dal giocatore. Anche nei videogiochi a scorrimento laterale, come Super Mario Bros e Moon Patrol, lo spazio si modifica seguendo i movimenti del giocatore, ma egli non può agire attivamente sulla schermata, che mostra, in automatico, tutti gli elementi necessari in quel frangente di gioco. Negli spazi concettuali, dunque, la percezione dell'occhio umano non è simulata poiché inadatta ai fini narrativi, come accade in Into the Breach (fig. 6) in cui la vista assonometrica, non distorcendo le dimensioni spaziali, consente di valutare distanze e direzioni con precisione, elementi strettamente necessari nei videogiochi di strategia.
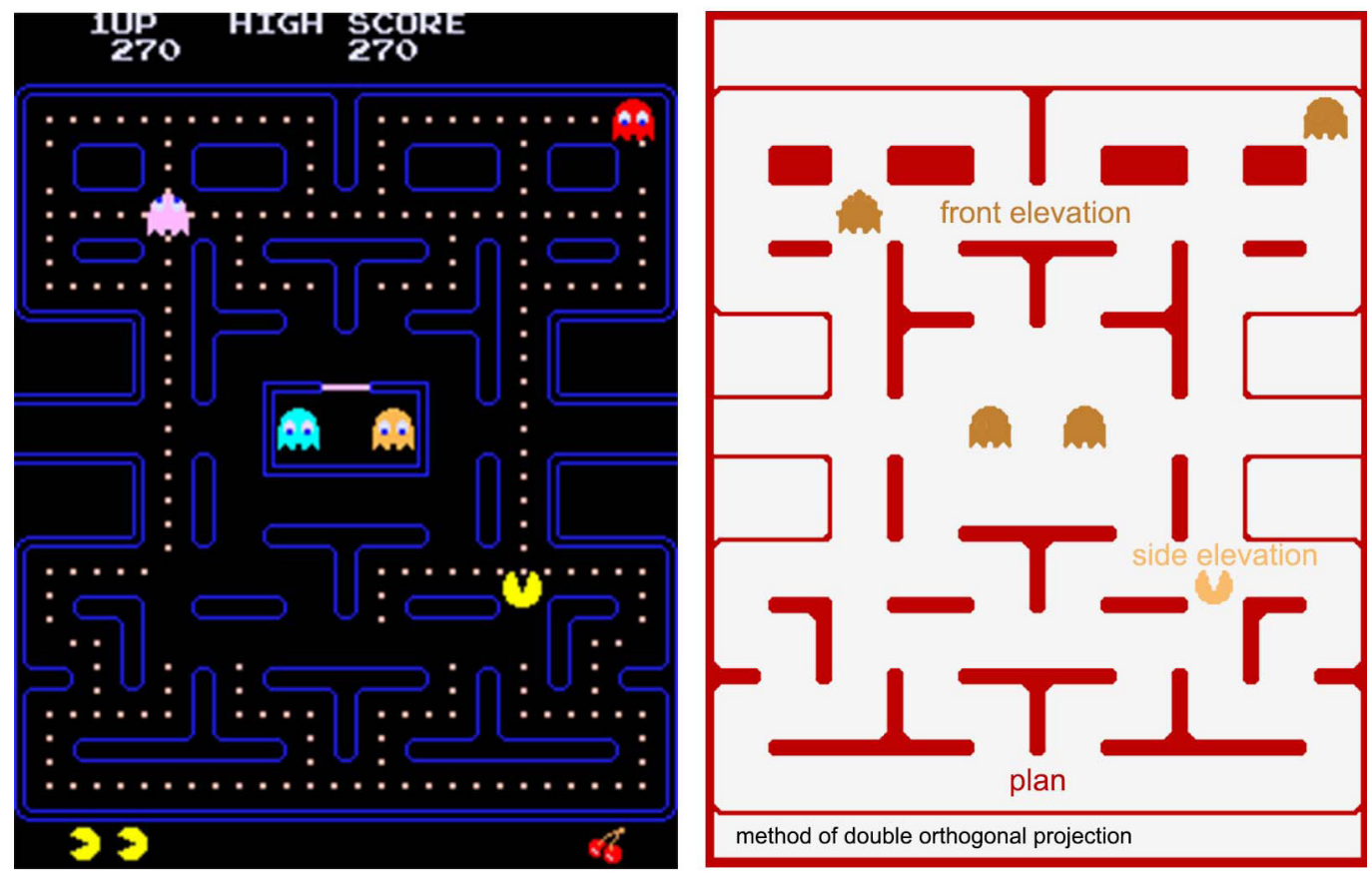

Conceptual Space in videogames 

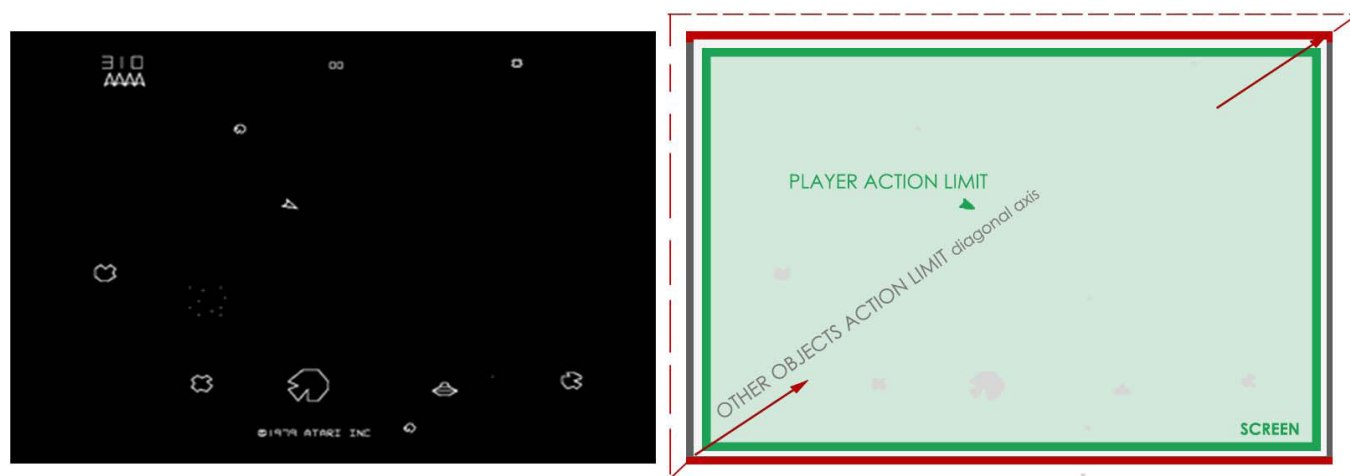

Fig. 5. La rappresentazione concettuale di uno spazio torico in Asteroids.

Il giocatore non controlla le relazioni spaziali nel fuoricampo.
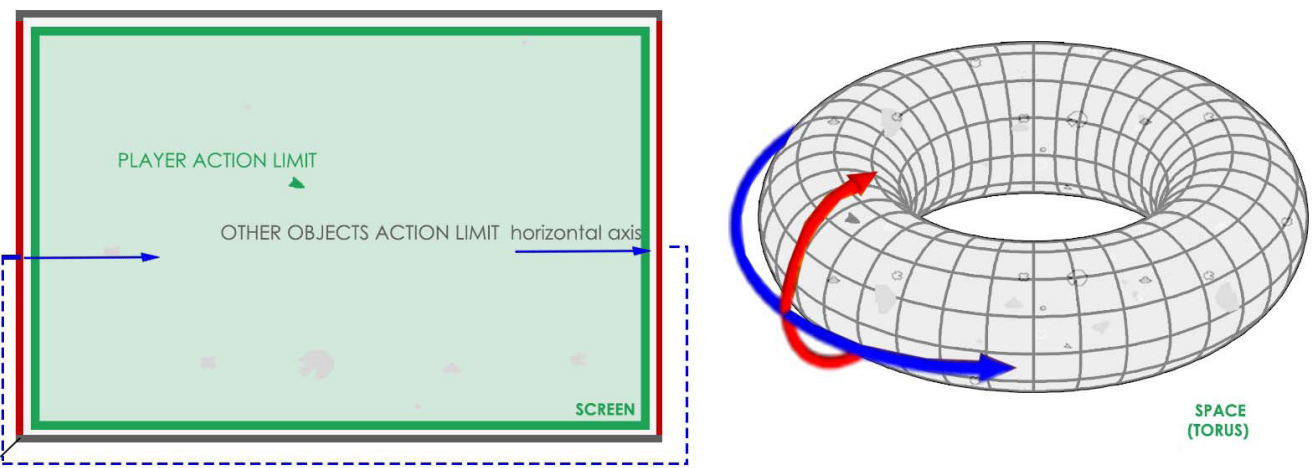

Fig. 6. La rappresentazione assonometrica in Into the Breach aiuta il giocatore nella interpretazione delle strategie di gioco.
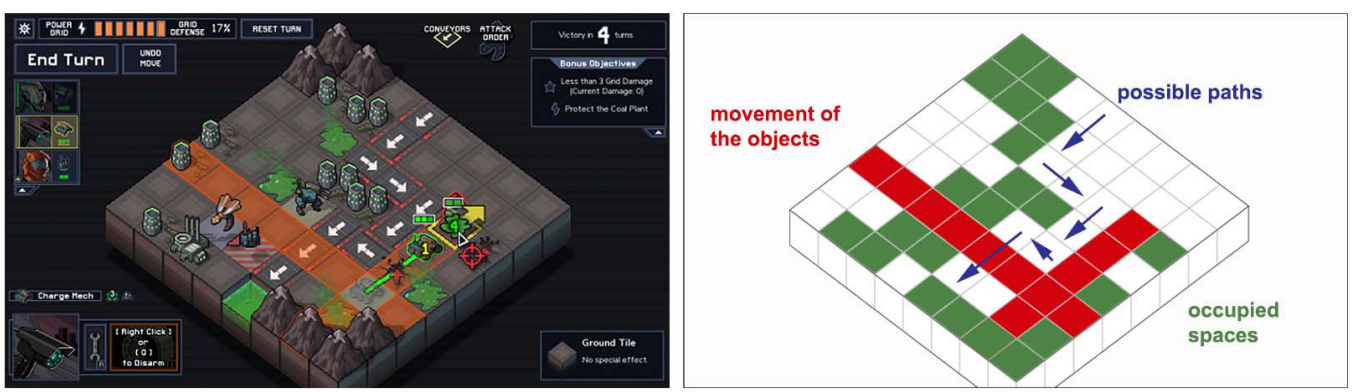

\section{Spazi visivi. Dalla pittura rinascimentale a Battlefield}

La pittura rinascimentale è visiva, poiché raffigura la forma apparente dello spazio simulandone la visione umana (fig. 7). Essa non solo simula la perspectiva naturalis, ma è anche in grado di sviluppare uno specifico procedimento scientifico, la perspectiva artificialis, al fine di riprodurla correttamente. La prospettiva è la forma simbolica del periodo rinascimentale [Panofsky 20 I3], in quanto identifica le esigenze di ordine razionale della cultura umanistica. Essa è un dispositivo abilitante che consente, attraverso un metodo fondato geometricamente, di "vedere attraverso" il dipinto [Panofsky 20।3, p. 35], che diventa una finestra di osservazione per lo spettatore, come se stesse assistendo direttamente alla scena spaziale. II metodo prospettico, dunque, si adatta alle esigenze narrative del tempo, relative al trionfo del senso della realtà, al dominio dell'uomo sul mondo, nella sua capacità di governare e gestire lo spazio, annullando ogni distanza tra realtà naturale e rappresentata. Dettagli, colori e luci, sempre conformi alle proporzioni determinate dal disegno prospettico, consentono all'osservatore di comprendere distanze e posizioni degli oggetti nella realtà spaziale, che 
Fig. 7. Da sopra a sotto, da sinistra a destra: Pinturicchio, Annunciazione, $150 \mid$ Cappella Baglioni, Spello; Piero della Francesca, Flagellazione, | 458-1459, Galleria Nazionale delle Marche Urbino: Paolo

Uccello, Miracolo dell'osti profanato 1467-1768, paria Nazionale Galle Nazionale delle Marche, Unino; Raffaello Sanzio, Scuola Atene, $1509-15$ Vaticani, Roma.

Fig. 8. La rappresentazione dello spazio visivo. Confronto tra la modalità di mira nel videogioco Battlefield e il funzionamento

dell'attrezzo prospettico di Filippo Brunelleschi.

Fig. 9. Battlefield, videogioco sparatutto del 2016. Schema della rappresentazione visiva dello spazio.
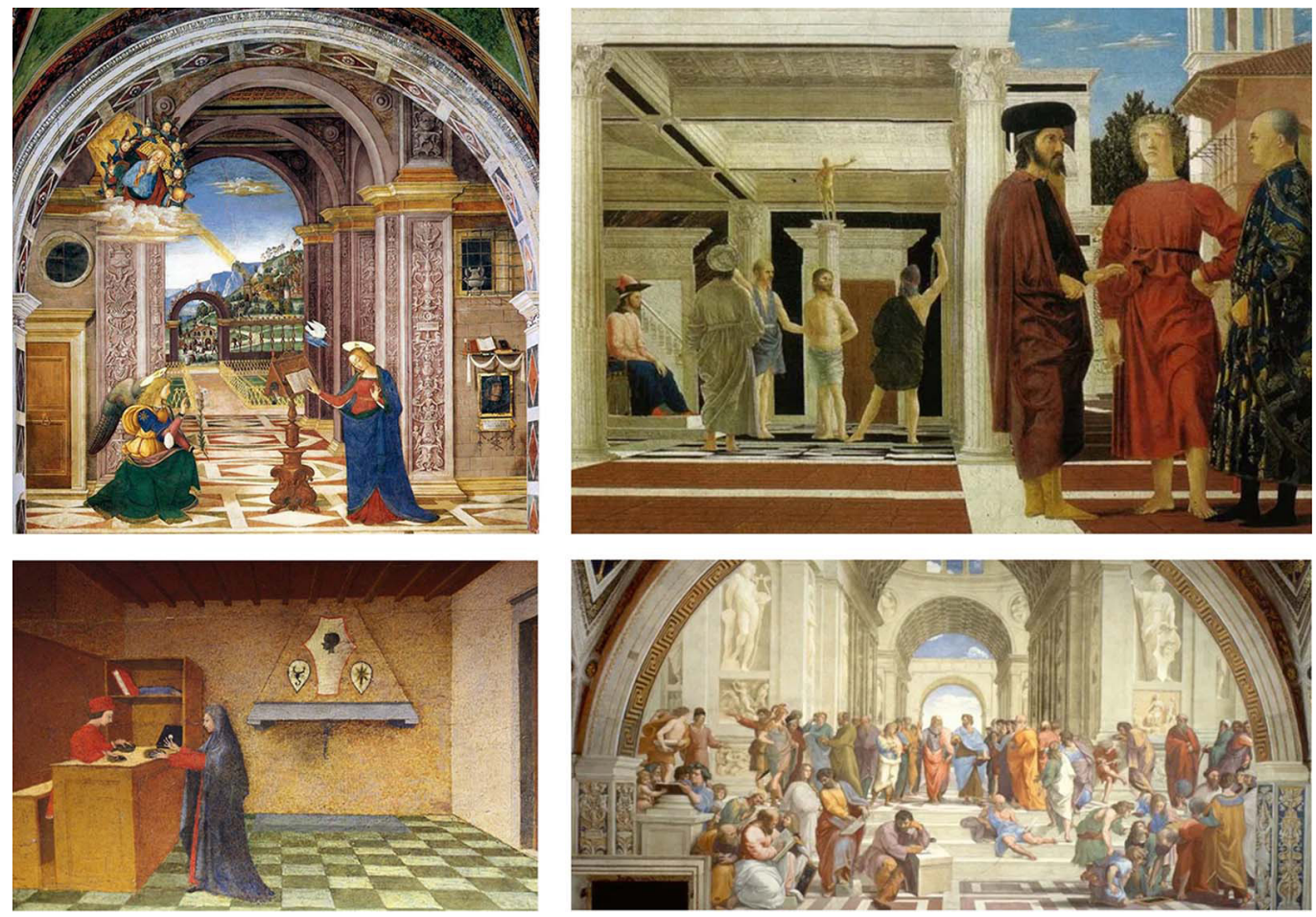

è rappresentata come "distinta dall'uomo, ma sul metro dell'uomo e delle sue relazioni" [Francastel 2005, p. 192]. Nei videogiochi, una rappresentazione dello spazio visivo si ritrova in Battlefield (figg. 8, 9). La prospettiva a unico punto di fuga fa sì che il giocatore inquadri lo spazio tridimensionale secondo la direzione del proprio sguardo, enfatizzandone il ruolo nell'assoluta gestione del campo visivo. Tale condizione si adatta ai caratteri narrativi del genere videoludico dello 'sparatutto', consentendo al giocatore di riconfigurare continuamen-
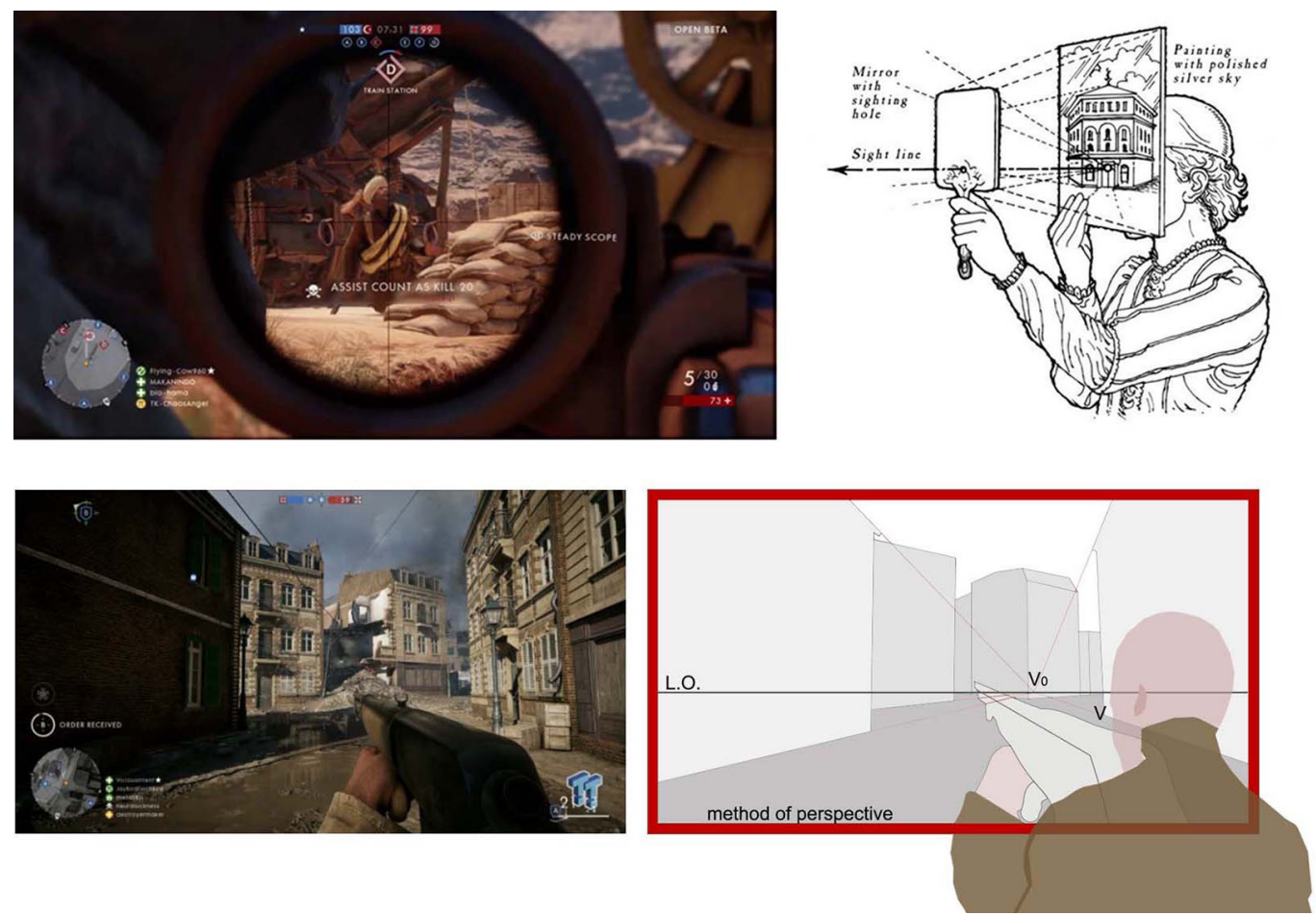
te il proprio campo visivo su ambienti differenti. L'importanza dell'unicità del punto di vista è inoltre testimoniata dal mirino dell'arma, posto sempre al centro dello schermo, con il quale il giocatore può autonomamente mettere a fuoco ciò che ritiene opportuno. II punto di vista del giocatore, coincidendo con quello dell'avatar, ne direziona i movimenti nello spazio. Le viste parziali, infatti, nascondono elementi narrativi anche nel fuoricampo, dunque l'esplorazione diviene azione necessaria per sviluppare la storia. La profondità non è rappresentata solo per dare maggiore realismo al gioco, ma permette al giocatore di comprendere i tempi necessari a percorrere lo spazio, oltre che i rapporti dimensionali tra gli oggetti. Ė per questo che vengono ripresi alcuni espedienti propri della pittura rinascimentale: lo sfumato, tipico delle prospettive aeree, indica che gli oggetti più distanti sono quelli dai contorni meno nitidi e dai colori più sfocati; l'uso di texture definite indica la vicinanza maggiore al punto di vista del giocatore; i rapporti tra luci e ombre chiariscono la posizione dell'avatar nello spazio [Pettinato 20 I8]. II punto di vista in prima persona, presente anche in videogiochi come FireWatch e Halo 4, non è una prerogativa assoluta degli spazi visivi. Anche gli spazi in Assassin's Creed, Grand Theft Auto e The Last Guardian sono visivi, pur essendo in terza persona. II punto di vista è comunque unico e corrisponde alla percezione spaziale assunta dal giocatore. L'avatar, inoltre, sempre di spalle, non ne altera la visione complessiva. In molti giochi, comunque, in cui è possibile passare dalla vista in prima a quella in terza persona, la rappresentazione dello spazio non cambia, essendo una sempre omotetia dell'altra (fig. I0).

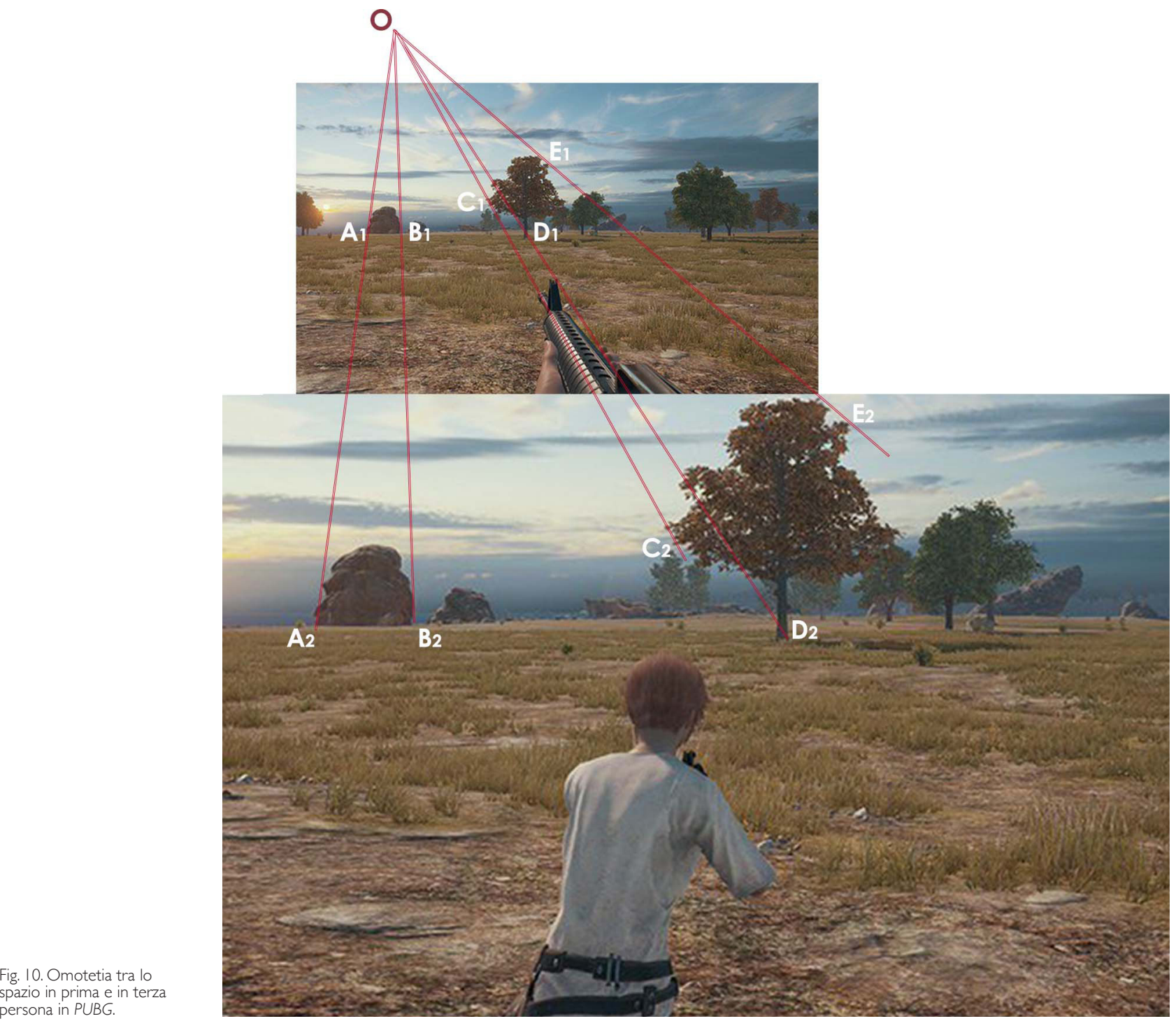




\section{Conclusioni}

La ricerca sottolinea come il nostro settore possa apportare un contributo fondamentale agli studi sul videogioco, inteso come forma narrativa in cui il disegno dello spazio è praticato quale modalità irrinunciabile per la costruzione di un codice visuale di pensiero. Le teorie relative alla costruzione dellimmagine spaziale in pittura permettono di comprendere come metodi e tecniche di rappresentazione, nonché elementi cardine del linguaggio visivo di tipo tradizionale, vengano reinterpretati nel videogioco per assumere un nuovo significato. L'interattività che esso propone, infatti, è decisamente più densa, poiché riguarda la manipolazione dello spazio. Quest'ultimo non è più un'estensione visiva delle strutture narrative convenzionali, ma diventa esso stesso una modalità di organizzazione del racconto, ricostruibile solo dal giocatore. II metodo comparativo evidenzia le differenze tra spazi concettuali e spazi visivi, definendone non solo i caratteri distintivi, ma anche le dinamiche che sono in grado di instaurare con azioni di gioco e struttura narrativa (fig. I I), consentendo così una catalogazione delle immagini videoludiche da parte dell'area scientifica del disegno e della rappresentazione (fig. I2).

Fig. I I. Comparazione delle caratteristiche deg spazi concettuali e degli spazi visivi nei videogiochi.

\begin{tabular}{|c|c|c|}
\hline & SPAZIO CONCETTUALE & SPAZIO VISIVO \\
\hline RELAZIONE CON LO SPAZIO REALE & $\begin{array}{l}\text { Non risponde ai principi di } \\
\text { verosimiglianza della percezione } \\
\text { reale }\end{array}$ & $\begin{array}{l}\text { Coincide con l'esperienza percettiva } \\
\text { dell'osservatore nello spazio reale }\end{array}$ \\
\hline PUNTO DI VISTA & $\begin{array}{l}\text { Simultaneità dei punti di vista, anche } \\
\text { in posizioni inaccessibili all'occhio } \\
\text { umano e non coincidenti con quello } \\
\text { dell'avatar }\end{array}$ & $\begin{array}{l}\text { Unicità del punto di vista del } \\
\text { giocatore, spesso coincidente con } \\
\text { quello dell'avatar }\end{array}$ \\
\hline PERCEZIONE DELLO SPAZIO & $\begin{array}{l}\text { La totalità dello spazio necessario } \\
\text { alla narrazione e al gameplay è } \\
\text { mostrato in un unico atto percettivo } \\
\text { globale e molteplice }\end{array}$ & $\begin{array}{l}\text { Lo spazio è inquadrato solo } \\
\text { parzialmente, è necessario che il } \\
\text { giocatore riconfiguri continuamente } \\
\text { il proprio campo visivo }\end{array}$ \\
\hline FOCALIZZAZIONE & Si focalizza sullo spazio stesso & $\begin{array}{l}\text { Si focalizza sullo sguardo che è } \\
\text { diretto sullo spazio }\end{array}$ \\
\hline $\begin{array}{l}\text { ELEMENTI CARDINE DEL LINGUAGGIO } \\
\text { VISIVO }\end{array}$ & $\begin{array}{l}\text { Astrazione } \\
\text { Schemi e tipi generali }\end{array}$ & $\begin{array}{l}\text { Verosimiglianza } \\
\text { Dettagli e particolari specifici }\end{array}$ \\
\hline $\begin{array}{l}\text { METODI DI RAPPRESENTAZIONE } \\
\text { PRIVILEGIATI }\end{array}$ & $\begin{array}{c}\text { Metodo di Monge e Assonometria, } \\
\text { volti ad un'oggettività comunicativa } \\
\text { dell'immagine spaziale, cosi come } \\
\text { accadeva nella rappresentazione } \\
\text { pittorica egizia }\end{array}$ & $\begin{array}{l}\text { Prospettiva, volta alla soggettività } \\
\text { del punto di vista nell'osservazione } \\
\text { dello spazio, cosi come accadeva } \\
\text { nella rappresentazione pittorica } \\
\text { rinascimentale }\end{array}$ \\
\hline RELAZIONE CON LE AZIONI DI GIOCO & $\begin{array}{l}\text { Controllo solo dello spazio entro la } \\
\text { schermata. Assenza del fuoricampo } \\
\text { (laddove esiste, non è gestito dal } \\
\text { giocatore). }\end{array}$ & $\begin{array}{l}\text { Controllo e gestione autonoma dello } \\
\text { spazio, sia entro la schermata che nel } \\
\text { fuoricampo (quest'ultimo sempre } \\
\text { esistente). }\end{array}$ \\
\hline $\begin{array}{l}\text { RELAZIONE CON LA STRUTTURA } \\
\text { NARRATIVA }\end{array}$ & $\begin{array}{l}\text { Ogni elemento svolge una funzione } \\
\text { equivalente nell'economia generale } \\
\text { del racconto. II ritmo narrativo è più } \\
\text { statico, il giocatore non modifica la } \\
\text { struttura narrativa spaziale }\end{array}$ & $\begin{array}{l}\text { Gli elementi svolgono funzioni } \\
\text { differenti nell'economia generale del } \\
\text { racconto. II ritmo narrativo è più } \\
\text { dinamico, il giocatore modifica la } \\
\text { struttura narrativa spaziale }\end{array}$ \\
\hline
\end{tabular}

Fig. 12. Esempio di catalogazıone delle immagini videoludic in relazione alla rappresentazione spaziale. Sull'asse delle ascisse, spaz concettuali e spazi visivi; sull'asse delle ordinate, rappresentazione bidimensionale (costanza allo 0\%) tridimensionale (costanza al $100 \%$ )

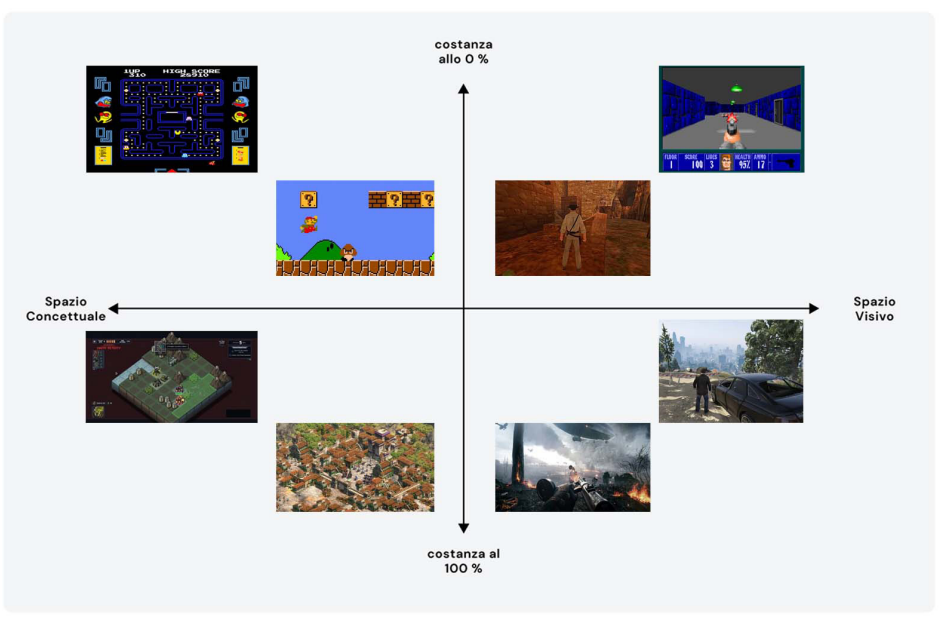




\section{Riferimenti bibliografici}

Adams E. (2002). Designer's Notebook: The Role of Architecture in Videogames. In Gamasutra. The Art \& Business of making games, October 2002. <https://www.gamasutra.com/view/feature/2943/designers_notebook_the_role_of_php?print=1> (consultato il 7 gennaio 202I)

Alinovi F. (2002). Serio videoludere. Spunti per una riflessione sul videogioco. In M. Bittanti. Per una cultura dei videogames. Teorie e prassi del video giocare, pp. 20-50. Milano: Edizioni Unicopoli.

Arnheim R. (1974). Il pensiero visivo. Torino: Einaudi.

Arnheim R. (2008). Arte e percezione visiva. Milano: Feltrinelli.

Barilli R. (2007). Scienza della cultura e fenomenologia degli stili. Bologna: Bononia University Press.

Cardone V. (20।9). Immaginare un'area culturale delle immagini visive. In XY Dimensioni del disegno, vol. I, n. I, maggio 20।9, pp. ||-27.

De Leo D. (2007). La fenomenologia della percezione estetica nel nuovo panorama multimediale. In P. Limone (a cura di). Nuovi media e formazione, pp. 263-288. Roma: Armando Editore.

De Rosa A., Sgrosso A., Giordano A. (2000). La geometria nell'immagine. Storia dei metodi di rappresentazione.Vol. I. Dall'antichità al Medio Evo. Milano: Utet.

Francastel P. (2005). Lo spazio figurativo dal Rinascimento al Cubismo. Sesto San Giovanni: Mimesis.

Fraschini B. (2002). Metal Gear Solid. L'evoluzione del Serpente. Milano: Unicopli.

Greenfield P. M. (1984). Mind and Media. The Effects of Television, Computers and Video Games. Hove, UK: Psychology Press.

Günzel S. (2008). The Space-Image. Interactivity and Spatiality of Computer Games. In S. Günzel, M. Liebe, M. Dieter (eds.). Philosophy of Computer Games, pp. 170- 189. Potsdam: University Press.

Maldonado T. (20I5). Reale e Virtuale. Milano: Feltrinelli Editore.

McCloud S. (1994). Understanding Comics. The Invisible Art. New York: HarperCollins Publisher.

Panosky E. (20|3). La prospettiva come "forma simbolica". Edizione illustrata. Milano: Abscondita.

Pecchinenda G. (20 I0). Videogiochi e cultura della simulazione: La nascita dell'homo game'. Roma-Bari:Laterza.

Pettinato G. (2018). Videogiochi e arte. Per una fenomenologia degli spazi videoludici. Bologna: ARTYPE.

Pierantoni R. (1981). L'occhio e l'idea. Fisiologia e storia della visione. Torino: Bollati Boringhieri.

Pierantoni R. (1986). Forma fluens: il movimento e la sua rappresentazione nella scienza, nell'arte e nella tecnica. Torino: Bollati Boringhieri.

Simondon G. (20I4). Sulla tecnica. Nocera Inferiore (SA): Orthotes.

Wolf M. J. P., Perron B. (2003). The Video Game Theory Reader. London: Routledge.

Zoran G. (1984). Towards a theory of space in narrative. In Poetics Today, vol. 5, pp. 309-335.

Zumthor P. (1995). La misura del mondo. La rappresentazione dello spazio nel Medio Evo. Bologna: II Mulino.

\section{Autore}

Greta Attademo, Università di Napoli “Federico II”, greta.attademo@unina.it

Per citare questo capitolo: Attademo Greta (202I). La rappresentazione dello spazio nei videogiochi/The representation of space in videogames. In Arena A., Arena M., Mediati D., Raffa P. (a cura di). Connettere. Un disegno per annodare e tessere. Linguaggi Distanze Tecnologie. Atti del $42^{\circ}$ Convegno Internazionale dei Docenti delle Discipline della Rappresentazione/Connecting. Drawing for weaving relationship. Languages Distances Technologies. Proceedings of the $42^{\text {th }}$ International Conference of Representation Disciplines Teachers. Milano: FrancoAngeli, pp. I03-122. 


\title{
The Representation of Space in Videogames
}

\author{
Greta Attademo
}

Abstract

The research investigates the visual language in the videogame, as a form of communication emblematic of the contemporary age. In particular we analyze the representation of space, as a common and central element in all visual narratives produced by man, whether static or dynamic images. The proposed theme, although partly addressed in the field of game studies, has not yet found a full response in the studies of the disciplinary field of drawing, probably due to the recent origin of the video game medium. The chosen methodology of analysis involves a comparison between pictorial and videogame spaces, since every form of visual narration takes up and reworks codes and languages from the media that preceded it, endowing them with new meaning. The theories related to the construction of spatial representation in a traditional art, different in temporal origin, type of images and narrative purposes, allow, in fact, to show more clearly repropositions and peculiarities of the new medium. The results obtained allow to define the possible relationships between drawing, narration and gameplay, constituting, moreover, a basis for the cataloging by the scientific area of the design of the spaces represented in videogames.

\section{Keywords}

videogames, gamespace, narrative space, visual culture, storytelling.

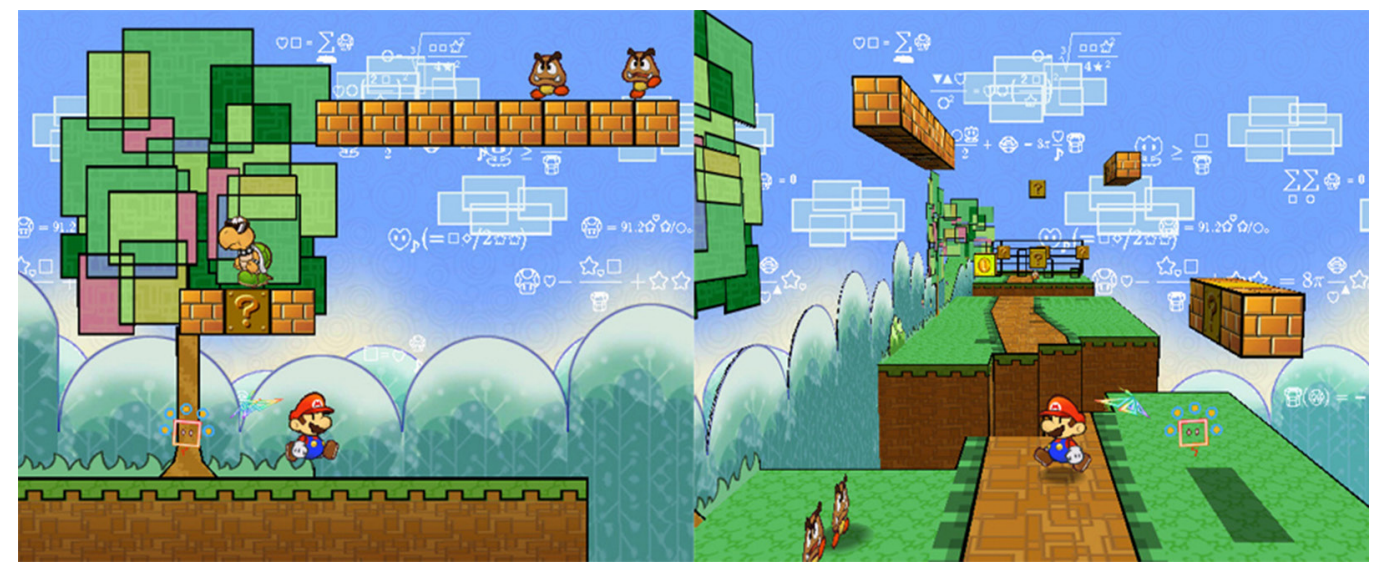




\section{Introduction}

Visual representation accompanies the history of man since his birth, responding to his need to narrate his perception of the world through a synthetic and universal code [McCloud 1994]. Throughout the centuries, it has been effective when interpreting the relationship between man and the world, revealing the perception of reality in which it was being established [Maldonado 20 15]. The videogame, whose intrinsic nature sees the convergence of visual language, technology and ludic experience, is the emblem of the contemporary era, dominated by an intercategorial fusion [Simondon 20 I 4] between human beings, digital artifacts and the external world. As Gianfranco Pecchinenda observes, "contemporary man has an image of himself that can be metaphorically represented by a videogame, in the sense that he considers himself a material entity predisposed to receive, process and communicate information with an external reality composed 'indifferently' of entities similar to himself, or of purely immaterial entities" [Pecchinenda 20 I0, p. 128]. Videogame analysis can redefine our relationship with narratives by images [Wolf, Perron 2003], considering that the image is perceived before the game [Gunzel 2008] and that "the visual component is not the exclusive dimension of the ludic and aesthetic experience, but undoubtedly the most pervasive" [De Leo 2007, p. 28 I]. Although "there are not a few people who think that our specific is not only architecture, but the elaboration of visual images" [Cardone 2019, p. 19], in our discipline there has not yet been the need to discuss this issue which, on the other hand, sees an increasingly intense participation of designers and architects in the creation of videogame products. As in other visual narratives, in fact, even in videogames is assigned a central role to the spatial representation, not only figuration of the place deputies to the action, but also category within which all the functional elements of the story are inserted [Zoran 1984]. The videogame, however, is the only medium that combines visual dynamism and active participatory role [Greenfield 1984]. If in other media the narrative is of "cause-and-effect" type, and the role of the viewer is to observe from the outside the dynamics of the story, in the videogame the interaction breaks this mechanism. The player is at the center of the story, he builds it through his actions [Adams 2002]. The ability "to manipulate the images reproduced on the screen" [Alinovi 2002, p. 17], implies a new relationship also with space. It is interesting, therefore, to investigate the visual languages of videogames while maintaining spatiality as the focus of research. Since the videogame recycles and reinvents the codes of traditional media [Fraschini 2002], we decide to compare its representations with those coming from pictorial art. The latter, which appears to be the narrative medium most different from videogames in terms of temporal origin, image staticity and 'analogue' component, allows us to show more clearly repropositions and peculiarities of the new medium.

\section{The representation of space in relation to reality}

Studies on visual art have shown how, within each socio-cultural context, it is possible to identify a system of images through which one takes possession of reality, identifying different ways of representation that reveal "the particular way in which man inhabits space and the mental relationships he has with it" [Zumthor 1995, p. 337]. Peter Zumthor distinguishes between 'conceptual' and 'figurative' images, depending on whether they operate by means of language or the mimetic arts" [Zumthor 1995, p. 15]. De Rosa too believes that the approach to spatial representation can be defined as 'conceptual' in those images "che pur caratterizzando antiche e raffinate civiltà artistiche $[\ldots]$ non ritennero utile fondare le proprie convenzioni rappresentative sulla verosimiglianza, pur nella consapevolezza del fenomeno oggettivo della prospettiva naturale" [De Rosa et al. 2000, p. I5]. For the opposite category, instead, he speaks of 'visual' images, as "il realismo, infatti, non è solo di tipo visivo, non si caratterizza cioè soltanto nell'imitare di un oggetto il modo in cui appare all'osservatore, ma si potrebbe alternativamente parlare di realismo metrico, cioè della restituzione grafica di alcuni valori dimensionali che si ritengono oggettivamente caratterizzanti una 
data forma" [De Rosa et al. 2000, p. 15]. There are, therefore, two types of representation: -conceptual space. It does not attempt to achieve any kind of visual realism, understood as a representation that is verisimilar to the human eye, but it reproduces the distinctive qualities of the real aspect of space.

-visual space. It represents space as it appears to the eyes of the observer, reproducing the physiological vision.

These categories respond to the spatial antipodes described by Rudolf Arnheim for pictorial compositions; not all representations are confined to these ends but, de facto, they always lean toward one of the two. The first, " $0 \%$ constancy" in which the drawing of space is reduced to the two-dimensionality of a single frontal plane; the second, "I $00 \%$ constancy", in which space is shown in a fully three-dimensional scene [Arnheim 2008, p. I I 5]. The analysis of some pictorial examples, overtly conceptual or visual, becomes a guideline for the study of videogame spaces.

\section{Conceptual spaces. From Egyptian painting to Pacman}

Egyptian painting is one of the clearest examples of the representation of conceptual space (fig. I). The Egyptians used orthogonal projections not because they were not aware of the physiological perception of the eye, nor because there was no scientific procedure that could be used (Roman painting, for example, simulated the three-dimensionality of space even though the perspective method had not yet been codified), but because they preferred it. This method, in fact, allows to preserve the most recognizable characters of the space [Arnheim 2008], communicating different and complex narrative sequences through a few intuitive signs. The two-dimensional figures, standing out against neutral backgrounds, are
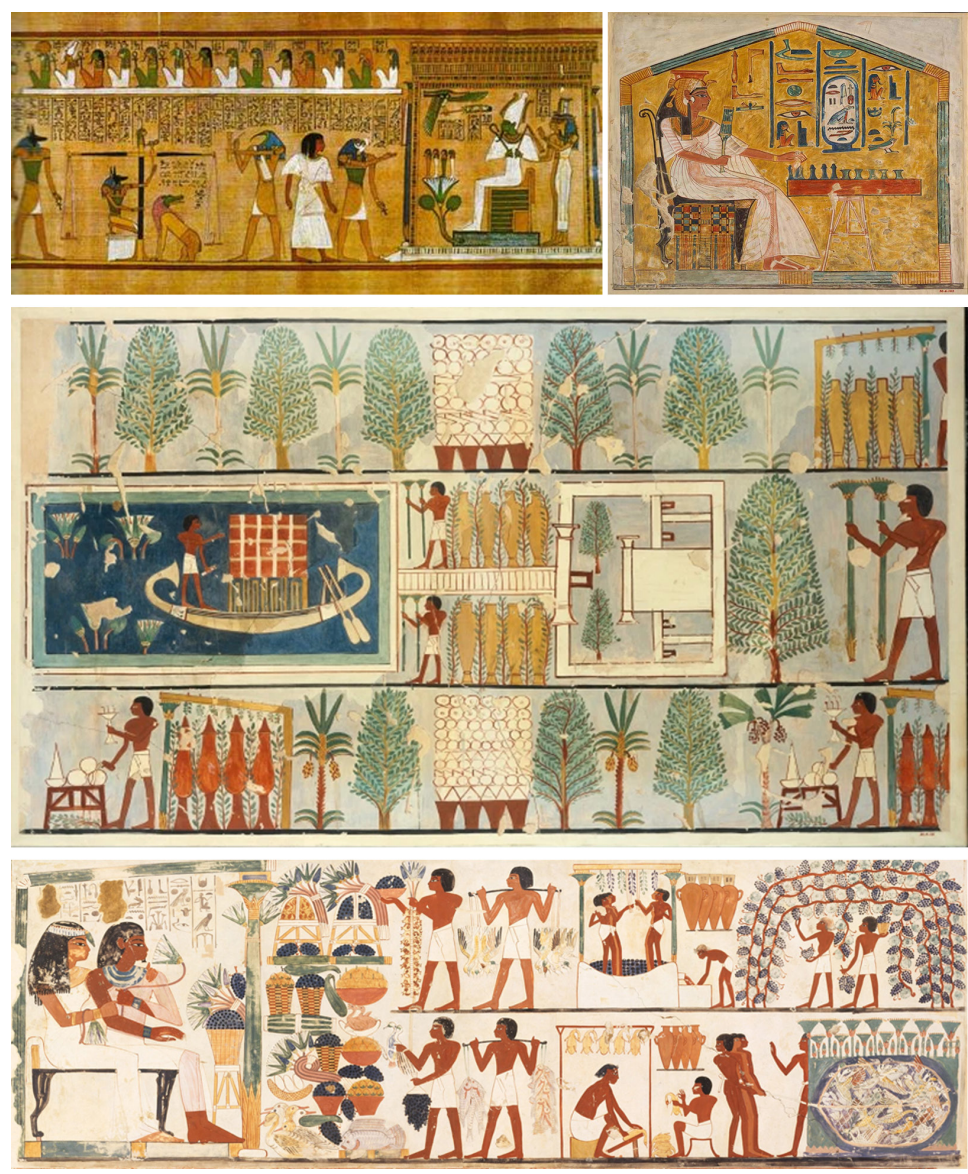
represented in their most recognizable profile, often breaking down and reassembling the parts to highlight the most significant qualities. The Garden of Nebamun (fig. 2), a fragment of wall painting dating back to around I 400 B.C., shows a global vision of space. The pool is in plan view, as such a projection allows for the preservation of length and width parameters, otherwise unobservable with other methods of representation. The fauna, consisting of fish and ducks, is in lateral perspective, so as to show feathers and fins that, although schematic, are essential to the recognition of animal species. The flora, in frontal perspective, makes visible not only the foliage of the plants, but also stems, branches and fruit, thus identifying the various types of trees, such as the palm and the sycamore. Moreover, the trees, tipped along the sides, indicate their position in relation to the pool. The conceptual space responds to the desire to narrate the garden as an icon of the lushness and varied richness of the Egyptian civilization, made possible by the climatic conditions and fertility of the soil. Also in

Fig. 2. II giardino ideale, fragment from the tomb of Nebamon (TT I46), Thebes, I8th dynasty, London, British Museum. Scheme of the conceptual representation of space.
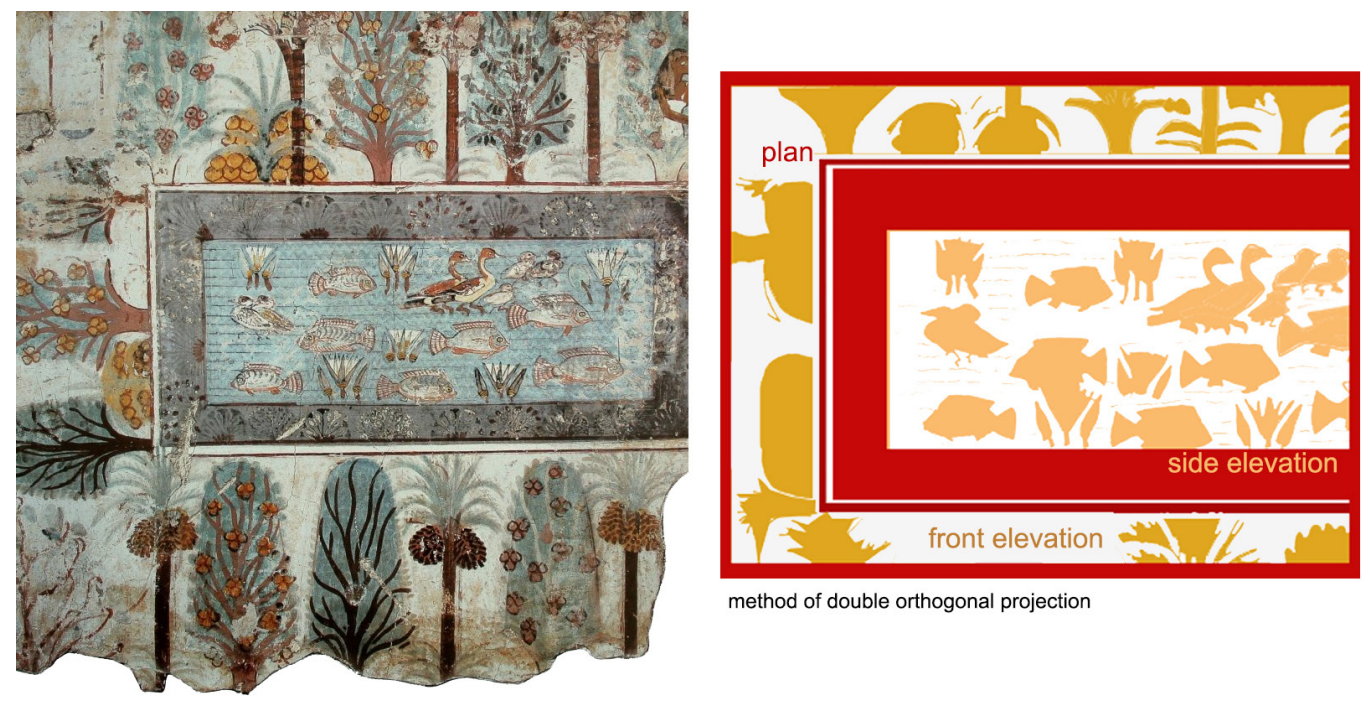

method of double orthogonal projection

Conceptual Space in painting

the videogame Pacman (figs. 3,4) a fixed framing shows the entire gamespace. The maze is in first orthogonal projection, giving a simultaneous vision of all the paths. The side profile of the Pacman avatar frames the opening of his mouth, otherwise not visible in a top-down view, connecting it to the game's purpose of eating the point elements placed along the paths. The ghosts, on the other hand, are in a frontal perspective that, by showing both eyes, communicates their ability to follow all of Pacman's movements, so as to reach and block him. The expansive, flat surface of the maze, emphasized by the black background, allows the space to be navigated only through sideways glides. The overlapping of spatial planes in a shared two-dimensional surface gives back an artifactual construction, dominated by the presence of all the elements inside the maze. The player, therefore, receives all spatial information through a single act of perception. His point of view, placed at infinity, does not coincide with that of the avatar, and this allows him to see beyond the walls, visualize the position of enemies and control the visible space. The abstraction of the elements (pure colors, stylized shapes, endogenous lights, absence of shading/reflections) emphasizes the clarity with which the space shows itself to the player's instant vision. The off-screen, therefore, contains no narrative elements to be revealed through exploration, which means resetting the boundaries of the frame. Although there are conceptual spaces that have relationships with the off-screen, the player is never allowed to control the field of view. In 
Fig. 3. The representation of conceptual space. Comparison between the videogame Pacman and the mural painting Giardino di Rekhmire,Tomb of Rekhmire, Sheikh Abd el-Qurna, c. O B.C.
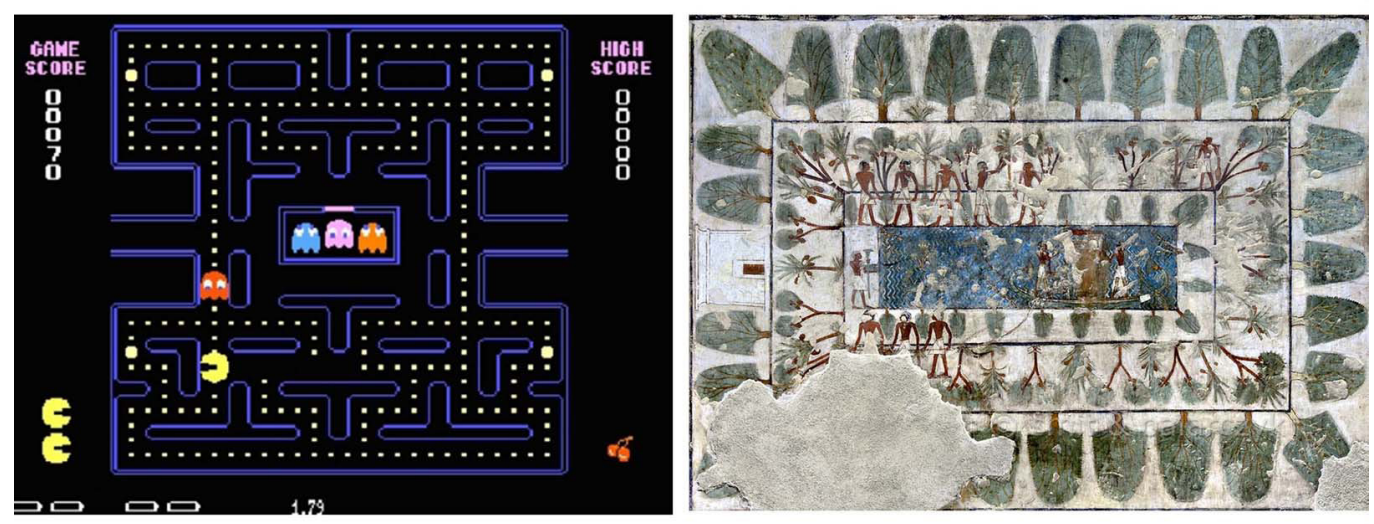

Asteroids (fig. 5), for example, some objects cross the boundaries of the two-dimensional surface, reappearing in the mirror side of their exit. The action of the spacecraft-avatar, on the other hand, is consumed within the boundaries of the frame, which cannot be modified by the player. Even in side-scrolling videogames, such as Super Mario Bros and Moon Patrol, the space is modified following the player's movements, but the player cannot actively act on the screen, which automatically shows all the elements necessary in that moment of the game. In conceptual spaces, therefore, the perception of the human eye is not simulated because it is unsuitable for narrative purposes, as it happens in Into the Breach (fig. 6) where the axonometric view, not distorting the spatial dimensions, allows to evaluate distances and directions with precision, elements strictly necessary in strategy videogames.
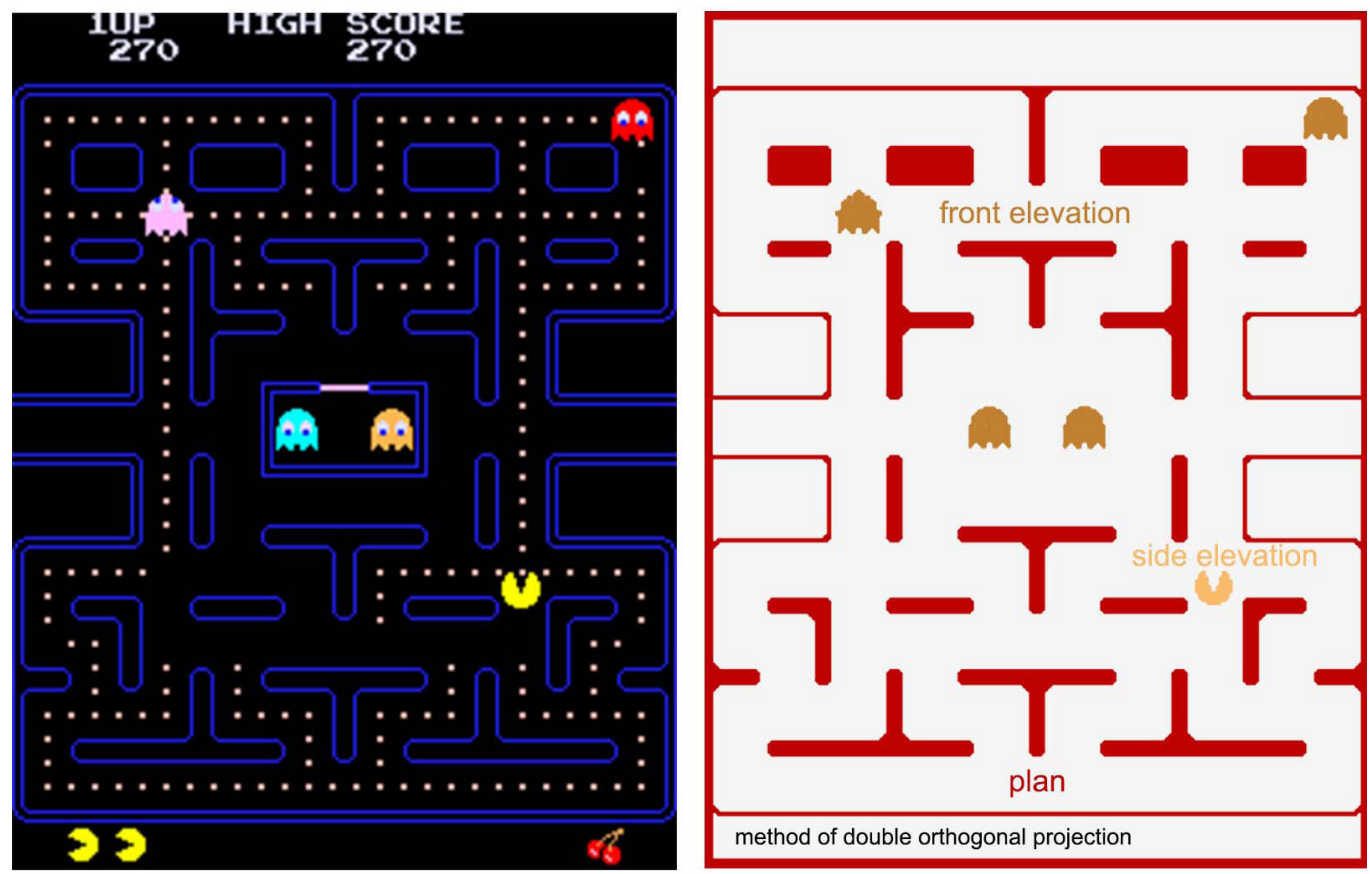

Conceptual Space in videogames

\section{Conceptual Space in videogames}



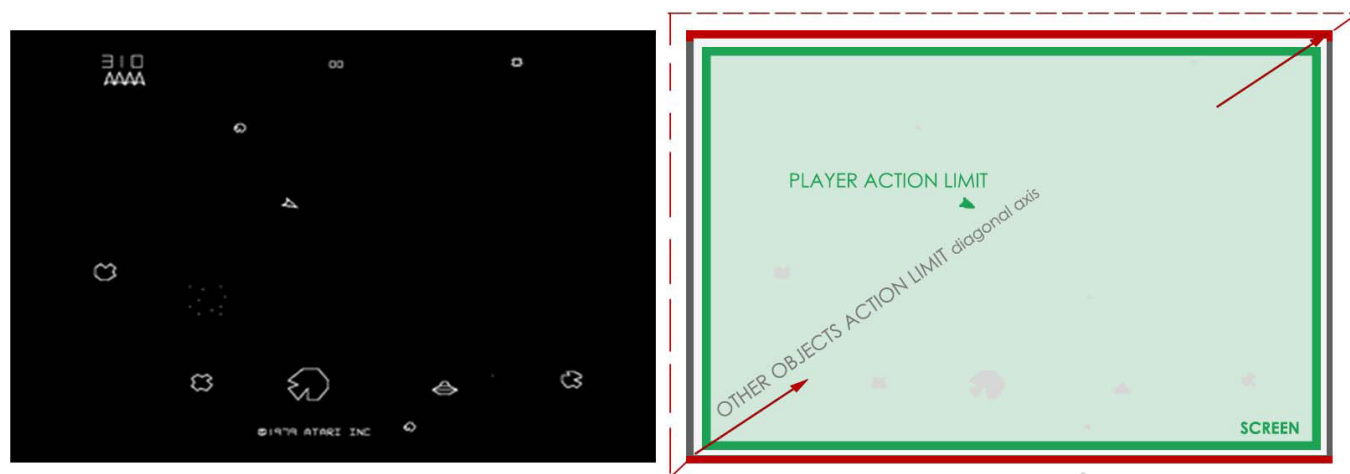

Fig. 5. The conceptual representation of a toric space in Asteroids. The player does not control the spatial relationships in the off-screen domain
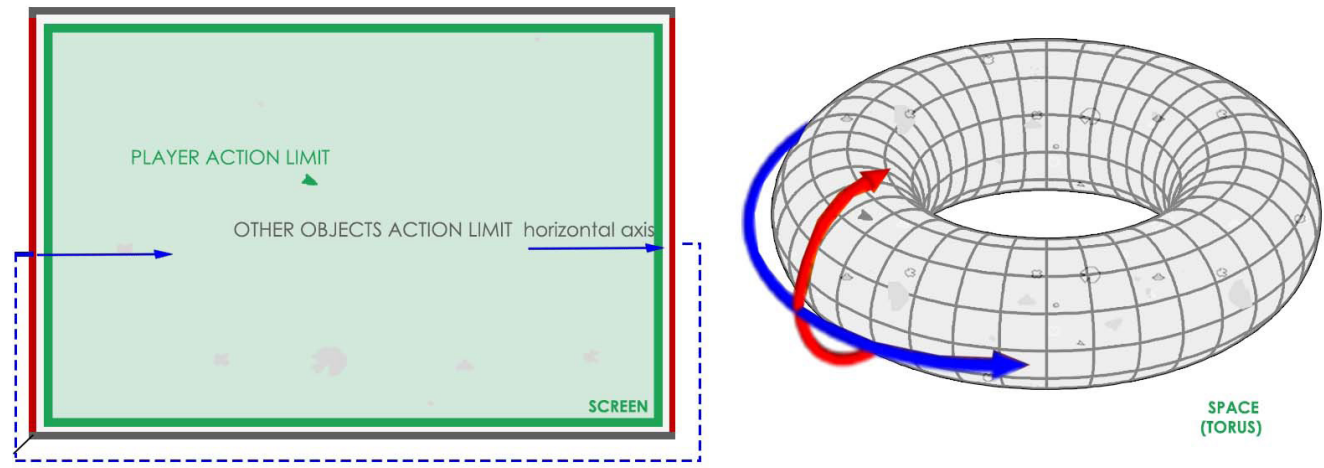

Fig. 6.The axonometric representation in Into the Breach helps the player in the interpretation of the game strategies.
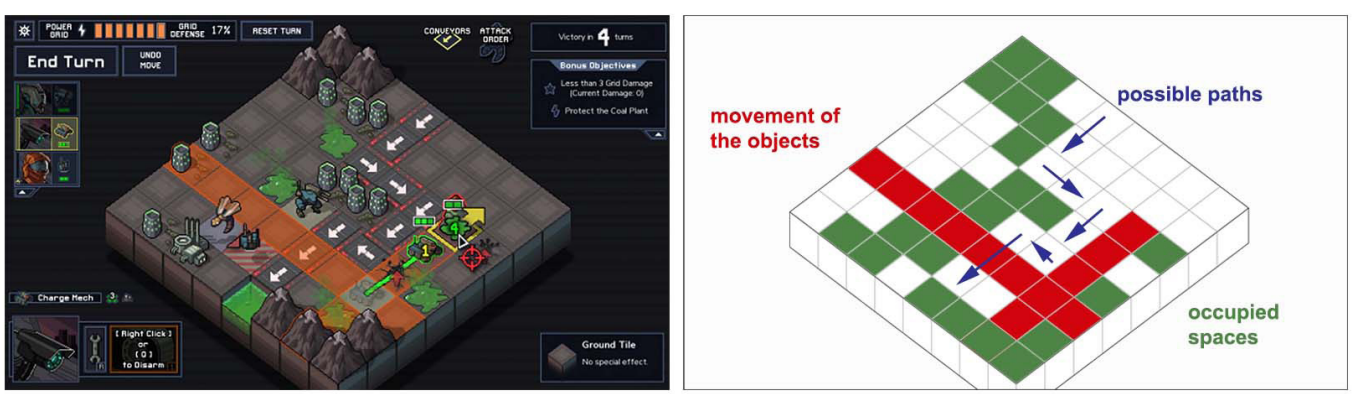

\section{Visual spaces. From Renaissance painting to Battlefield}

Renaissance painting is visual, since it depicts the apparent form of space by simulating human vision (fig. 7). It not only simulates the perspectiva naturalis, but is also able to develop a specific scientific procedure, the perspectiva artificialis, in order to reproduce it correctly. Perspective is the symbolic form of the Renaissance period [Panofsky 2013], as it identifies the rational order requirements of humanistic culture. It is an enabling device that allows, through a geometrically grounded method, to "see through" the painting [Panofsky 20 I 3, p. 35], which becomes a window of observation for the viewer, as if he were directly witnessing the spatial scene. The perspective method, therefore, is adapted to the narrative needs of the time, related to the triumph of the sense of reality, the dominance of man over the world, in his ability to govern and manage space, canceling any distance between natural and represented reality. Details, colors and lights, always conforming to the proportions determined by the perspective drawing, allow the observer to understand distances and positions of objects in the spatial reality, which is represented as "distinct from man, but on 
Fig. 7. Top to bottom, left to right: Pinturicchio, Annunciazione, 1501 Cappella Baglioni, Spello Piero della Francesca, Flagellazione, 1458-1459, Galleria Nazionale delle Marche, Urbino; Paolo Uccello, Miracolo dell'ostio profanata, |467-|468, Galleria Nazionale delle Marche, Urbino: Raffaello Sanzio, Scuolo di Atene, |509-15| I, Vaticani, Rome.

Fig. 8. The representation of visual space. Comparison between the shooting mode in the videogame Battlefield and the functioning of Filippo Brunelleschi's perspective

Fig. 9. Battlefield, videogioco sparatutto del 2016. Shooter videogame. Scheme of the visual representation of space.
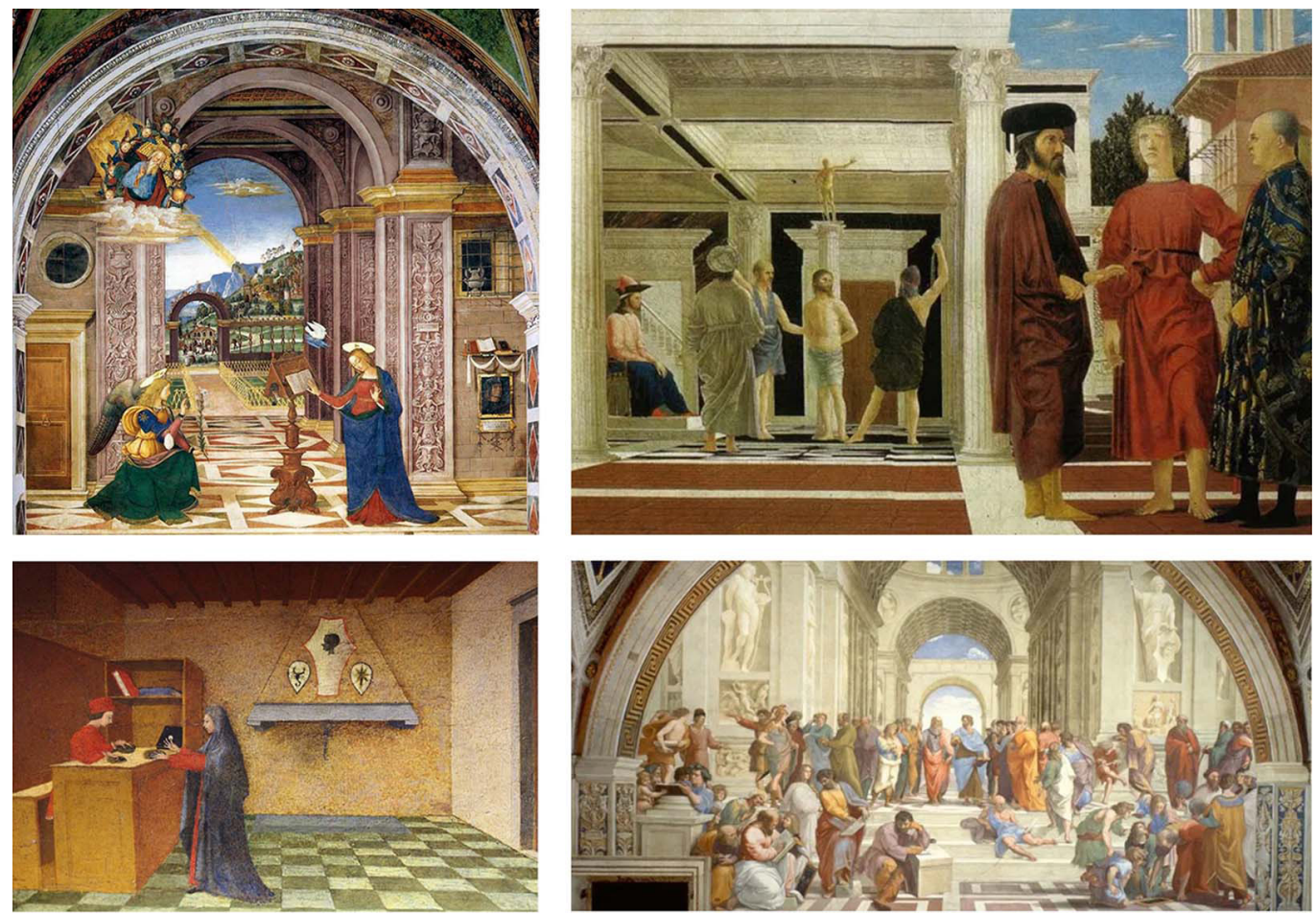

the meter of man and his relations" [Francastel 2005, p. 192]. In videogames, a representation of visual space can be found in Battlefield (figs. 8, 9). The single vanishing point perspective makes the player frame the three-dimensional space according to the direction of his gaze, emphasizing the role of the player in the absolute management of the visual field. This condition fits the narrative characteristics of the shooter genre, allowing the player to continuously reconfigure his field of view on different environments. The importance of
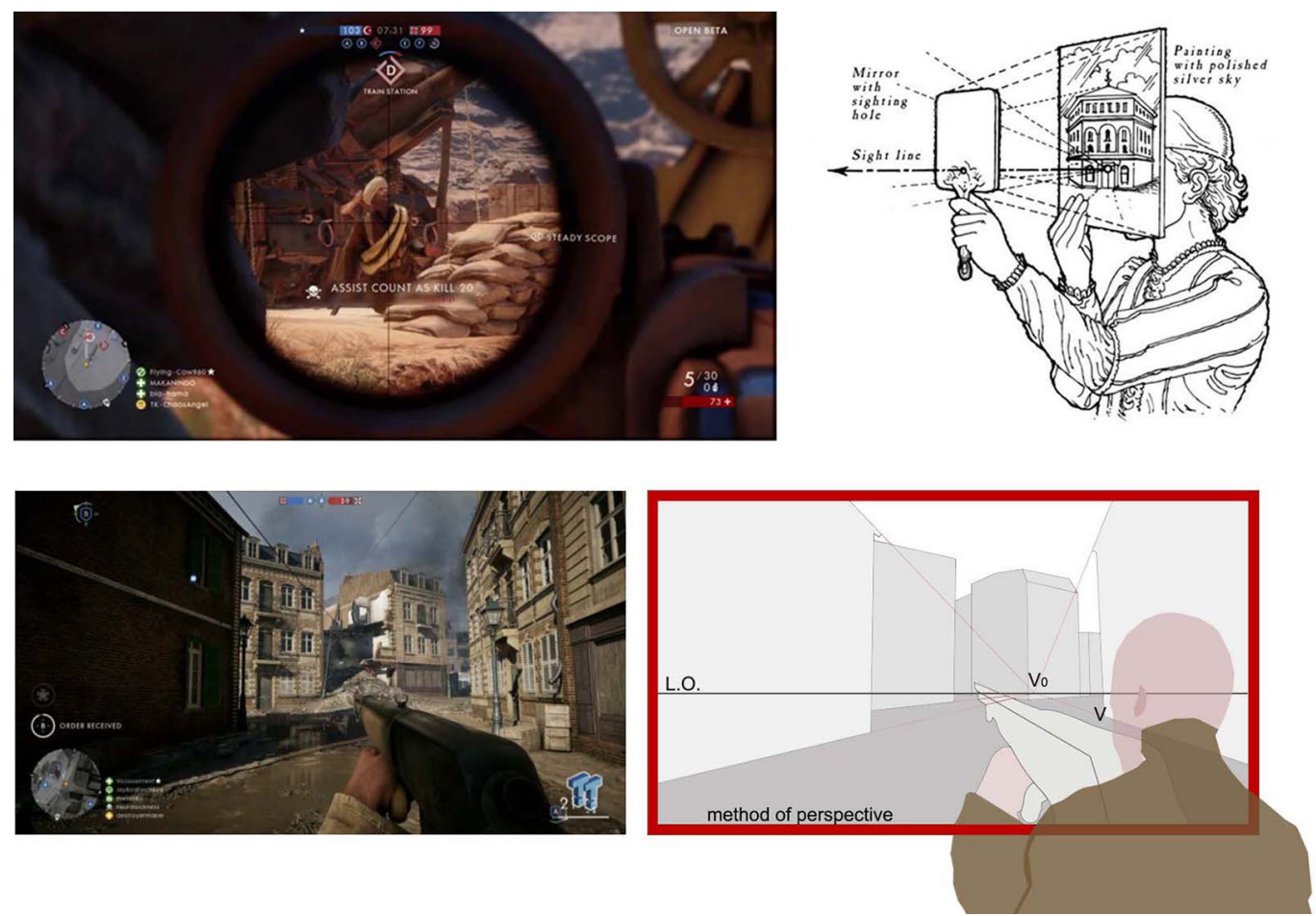
the uniqueness of the point of view is also witnessed by the weapon's viewfinder, always placed in the center of the screen, with which the player can autonomously focus on what he considers appropriate. The player's point of view coincides with the avatar's point of view, directing its movements in space. The partial views, in fact, hide narrative elements even in the off-screen, so the exploration becomes a necessary action to develop the story. Depth is not only represented to give more realism to the game, but it allows the player to understand the time required to travel through space, as well as the dimensional relationships between objects. This is why some tricks typical of Renaissance painting are taken up: the gradient, typical of aerial perspectives, indicates that the most distant objects are those with less sharp contours and more blurred colors; the use of defined textures indicates greater proximity to the player's point of view; the relationships between light and shadow clarify the avatar's position in space [Pettinato 20 I8]. The first-person point of view, also present in videogames such as FireWatch and Halo 4, is not an absolute prerogative of visual spaces. The spaces in Assassin's Creed, Grand Theft Auto, and The Last Guardian are also visual, despite being in the third person. The point of view is however unique and corresponds to the spatial perception assumed by the player. The avatar, moreover, always with his back to the player, does not alter the overall view. In many games, however, where it is possible to switch from first-person to third-person view, the representation of space does not change, since one is always homothetic to the other (fig. I0).

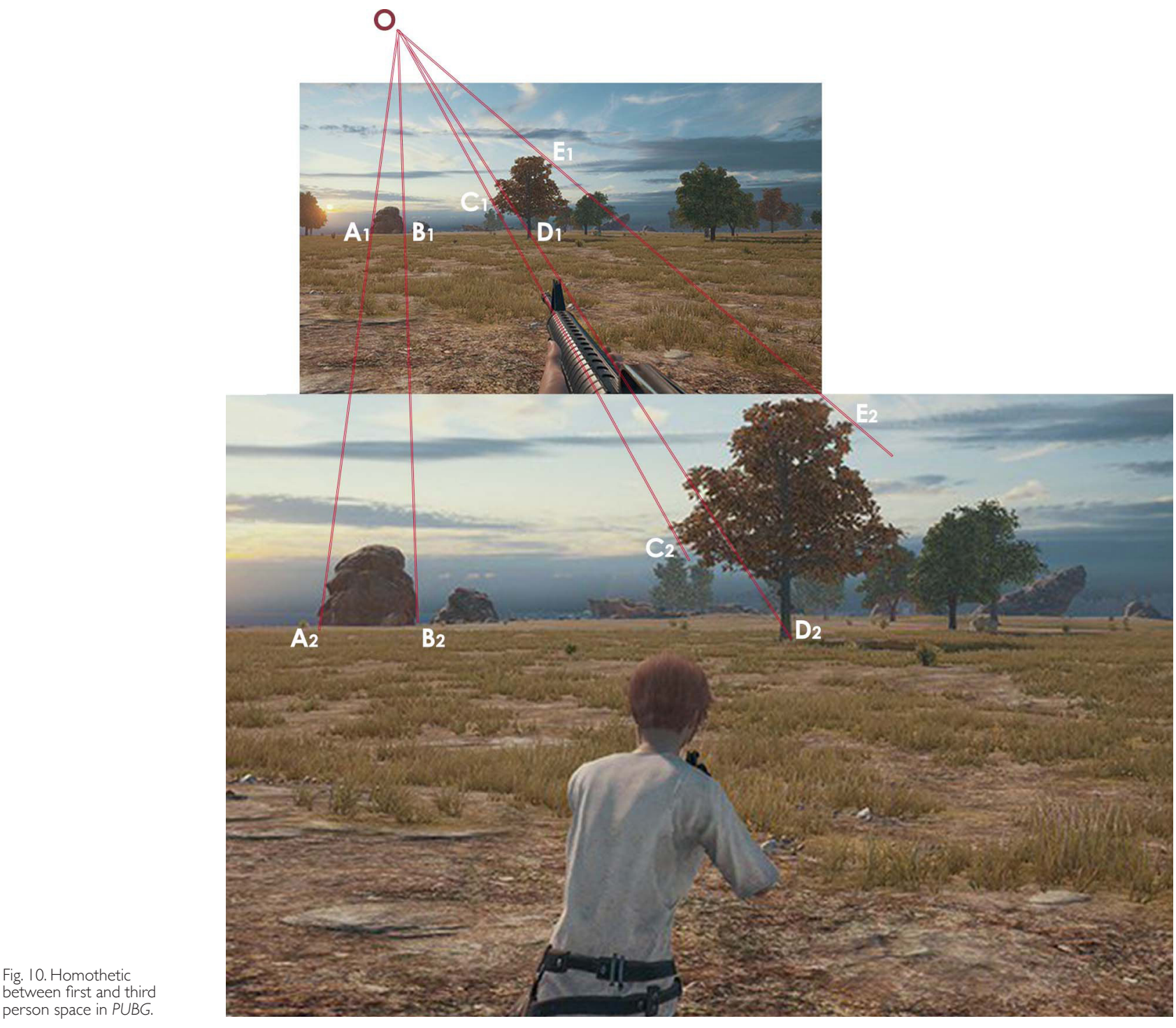




\section{Conclusions}

The research underlines how our field can make a fundamental contribution to the studies on videogames, understood as a narrative form in which the drawing of space is practiced as an essential modality for the construction of a visual code of thought. The theories related to the construction of the spatial image in painting, allow us to understand how methods and techniques of representation, as well as key elements of traditional visual language, are reinterpreted in the videogame to take on a new meaning. The interactivity that it proposes, in fact, is much denser, since it concerns the manipulation of space. Space is no longer a visual extension of conventional narrative structures, but it becomes a way of organizing the story, which can be reconstructed only by the player. The comparative method highlights the differences between conceptual and visual spaces, defining not only their distinctive features, but also the dynamics that they are able to establish with the game actions and the narrative structure (fig. I I), thus allowing a cataloguing of videogame images by the scientific area of design and representation (fig. I2).

Fig. I I. Comparison of the features of conceptual and visual spaces in videogames.
Fig. 12. Example of cataloging videogame images in relation to spatial representation. On the $x$-axis,

conceptual spaces and visual spaces: on the $y$-axis, two-dimensional representation

(0\% constancy) or

three-dimensional

representation (100\% constancy).

\begin{tabular}{|c|c|c|}
\hline & SPAZIO CONCETTUALE & SPAZIO VISIVO \\
\hline RELAZIONE CON LO SPAZIO REALE & $\begin{array}{l}\text { Non risponde ai principi di } \\
\text { verosimiglianza della percezione } \\
\text { reale }\end{array}$ & $\begin{array}{l}\text { Coincide con l'esperienza percettiva } \\
\text { dell'osservatore nello spazio reale }\end{array}$ \\
\hline PUNTO DI VISTA & $\begin{array}{l}\text { Simultaneità dei punti di vista, anche } \\
\text { in posizioni inaccessibili all'occhio } \\
\text { umano e non coincidenti con quello } \\
\text { dell'avatar }\end{array}$ & $\begin{array}{l}\text { Unicità del punto di vista del } \\
\text { giocatore, spesso coincidente con } \\
\text { quello dell'avatar }\end{array}$ \\
\hline PERCEZIONE DELLO SPAZIO & $\begin{array}{l}\text { La totalità dello spazio necessario } \\
\text { alla narrazione eal gameplay } \\
\text { mostrato in un unico atto percettivo } \\
\text { globale e molteplice }\end{array}$ & $\begin{array}{l}\text { Lo spazio è inquadrato solo } \\
\text { parzialmente, è necessario che il } \\
\text { giocatore riconfiguri continuamente } \\
\text { il proprio campo visivo }\end{array}$ \\
\hline FOCALIZZAZIONE & Si focalizza sullo spazio stesso & $\begin{array}{l}\text { Si focalizza sullo sguardo che è } \\
\text { diretto sullo spazio }\end{array}$ \\
\hline $\begin{array}{l}\text { ELEMENTI CARDINE DEL LINGUAGGIO } \\
\text { VISIVO }\end{array}$ & $\begin{array}{l}\text { Astrazione } \\
\text { Schemi e tipi generali }\end{array}$ & $\begin{array}{l}\text { Verosimiglianza } \\
\text { Dettagli e particolari specifici }\end{array}$ \\
\hline $\begin{array}{l}\text { METODI DI RAPPRESENTAZIONE } \\
\text { PRIVILEGIATI }\end{array}$ & $\begin{array}{c}\text { Metodo di Monge e Assonometria, } \\
\text { volti ad un'oggettività comunicativa } \\
\text { dell'immagine spaziale, cosi come } \\
\text { accadeva nella rappresentazione } \\
\text { pittorica egizia }\end{array}$ & $\begin{array}{l}\text { Prospettiva, volta alla soggettività } \\
\text { del punto di vista nell'osservazione } \\
\text { dello spazio, cosi come accadeva } \\
\text { nella rappresentazione pittorica } \\
\text { rinascimentale }\end{array}$ \\
\hline RELAZIONE CON LE AZIONI DI GIOCO & $\begin{array}{l}\text { Controllo solo dello spazio entro la } \\
\text { schermata. Assenza del fuoricampo } \\
\text { (laddove esiste, non è gestito dal } \\
\text { giocatore). }\end{array}$ & $\begin{array}{l}\text { Controllo e gestione autonoma dello } \\
\text { spazio, sia entro la schermata che nel } \\
\text { fuoricampo (quest'ultimo sempre } \\
\text { esistente). }\end{array}$ \\
\hline $\begin{array}{l}\text { RELAZIONE CON LA STRUTTURA } \\
\text { NARRATIVA }\end{array}$ & $\begin{array}{l}\text { Ogni elemento svolge una funzione } \\
\text { equivalente nell'economia generale } \\
\text { del racconto. Il ritmo narrativo è più } \\
\text { statico, il giocatore non modifica la } \\
\text { struttura narrativa spaziale }\end{array}$ & $\begin{array}{l}\text { Gli elementi svolgono funzioni } \\
\text { differenti nell'economia generale del } \\
\text { racconto. II ritmo narrativo è più } \\
\text { dinamico, il giocatore modifica la } \\
\text { struttura narrativa spaziale }\end{array}$ \\
\hline
\end{tabular}

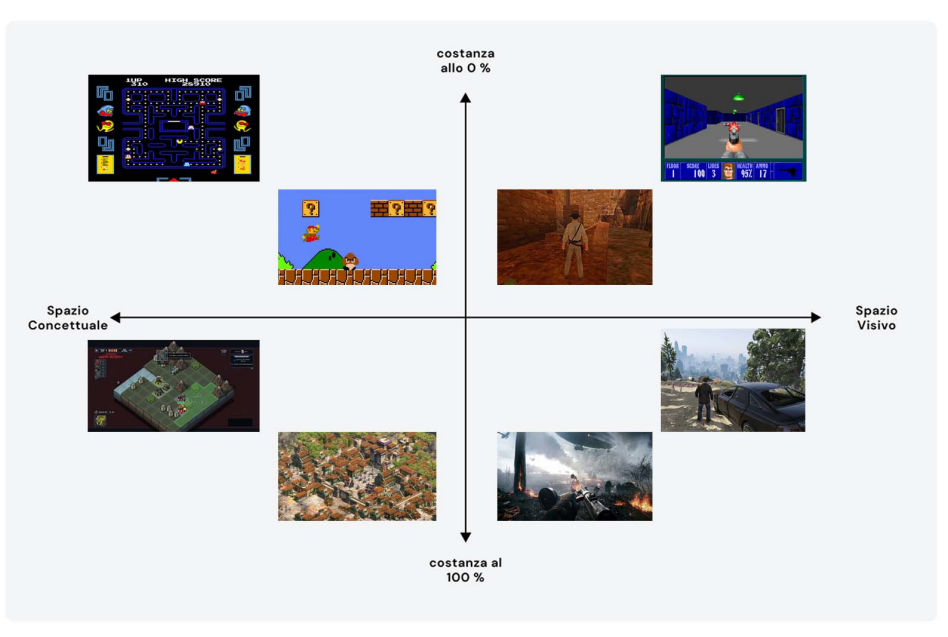




\section{References}

Adams E. (2002). Designer's Notebook: The Role of Architecture in Videogames. In Gamasutra. The Art \& Business of making games, October 2002. <https://www.gamasutra.com/view/feature/2943/designers_notebook_the_role_of_php?print=1> (accessed on 2021, January 7)

Alinovi F. (2002). Serio videoludere. Spunti per una riflessione sul videogioco. In M. Bittanti. Per una cultura dei videogames. Teorie e prassi del video giocare, pp. 20-50. Milano: Edizioni Unicopoli.

Arnheim R. (1974). Il pensiero visivo. Torino: Einaudi.

Arnheim R. (2008). Arte e percezione visiva. Milano: Feltrinelli.

Barilli R. (2007). Scienza della cultura e fenomenologia degli stili. Bologna: Bononia University Press.

Cardone V. (20।9). Immaginare un'area culturale delle immagini visive. In XY Dimensioni del disegno, vol. I, n. I, maggio 20।9, pp. ||-27.

De Leo D. (2007). La fenomenologia della percezione estetica nel nuovo panorama multimediale. In P. Limone (a cura di). Nuovi media e formazione, pp. 263-288. Roma: Armando Editore.

De Rosa A., Sgrosso A., Giordano A. (2000). La geometria nell'immagine. Storia dei metodi di rappresentazione.Vol. I. Dall'antichità al Medio Evo. Milano: Utet

Francastel P. (2005). Lo spazio figurativo dal Rinascimento al Cubismo. Sesto San Giovanni: Mimesis.

Fraschini B. (2002). Metal Gear Solid. L'evoluzione del Serpente. Milano: Unicopli.

Greenfield P. M. (1984). Mind and Media. The Effects of Television, Computers and Video Games. Hove, UK: Psychology Press.

Günzel S. (2008). The Space-Image. Interactivity and Spatiality of Computer Games. In S. Günzel, M. Liebe, M. Dieter (eds.). Philosophy of Computer Games, pp. 170- 189. Potsdam: University Press.

Maldonado T. (20I5). Reale e Virtuale. Milano: Feltrinelli Editore.

McCloud S. (1994). Understanding Comics. The Invisible Art. New York: HarperCollins Publisher.

Panosky E. (20|3). La prospettiva come "forma simbolica". Edizione illustrata. Milano: Abscondita.

Pecchinenda G. (20 I0). Videogiochi e cultura della simulazione: La nascita dell'homo game'. Roma-Bari:Laterza.

Pettinato G. (20 I8). Videogiochi e arte. Per una fenomenologia degli spazi videoludici. Bologna: ARTYPE.

Pierantoni R. (198I). L'occhio e l'idea. Fisiologia e storia della visione. Torino: Bollati Boringhieri.

Pierantoni R. (1986). Forma fluens: il movimento e la sua rappresentazione nella scienza, nell'arte e nella tecnica. Torino: Bollati Boringhieri.

Simondon G. (20|4). Sulla tecnica. Nocera Inferiore (SA): Orthotes.

Wolf M. J. P., Perron B. (2003). The Video Game Theory Reader. London: Routledge.

Zoran G. (1984). Towards a theory of space in narrative. In Poetics Today, vol. 5, pp. 309-335.

Zumthor P. (1995). La misura del mondo. La rappresentazione dello spazio nel Medio Evo. Bologna: II Mulino.

\section{Author \\ Greta Attademo, Università di Napoli “Federico II”, greta.attademo@unina.it}

To cite this chapter. Attademo Greta (2021). La rappresentazione dello spazio nei videogiochi/The representation of space in videogames. In Arena A., Arena M., Mediati D., Raffa P. (a cura di). Connettere. Un disegno per annodare e tessere. Linguaggi Distanze Tecnologie. Atti del $42^{\circ}$ Convegno Internazionale dei Docenti delle Discipline della Rappresentazione/Connecting. Drawing for weaving relationship. Languages Distances Technologies. Proceedings of the $42^{\text {th }}$ International Conference of Representation Disciplines Teachers. Milano: FrancoAngeli, pp. I03-122. 